\title{
Bozköy'de Kadın ve Erkeğin Mekân Kullanımında Toplumsal Cinsiyet Rolleri: Etnoarkeolojik Bir Yaklaşım
}

\author{
Serhan MUTLU*
}

\section{ÖZET}

Araştırma kapsamında Kuzeybatı Anadolu'da Biga Yarımadası'nda (Troas) Bozköy'de toplumsal cinsiyet rollerini anlamaya yönelik etnografik çalışma yapılmıştır. Etnografik çalışmanın amacı ilerleyen dönemlerde kazısı ve araştırılması planlanan prehistorik dönem Bozköy-Hanaytepe Höyügü̈'ne toplumsal cinsiyet rolleri ile ilgili etnoarkeolojik temel veriler hazırlayıp toplumsal cinsiyet rolleri üzerine dikkat çekmektir. Çalışmada Bozköy'deki izlenimler neticesinde toplumsal cinsiyet rollerini özel, kamusal alan ve tarım arazileri başlıkları altında mekân içi ve mekân dışı bağlamında değerlendirilmiştir. Mekân içi ve mekân dişı iş bölümlerinde mimari öğelerden çokça yararlanılmıştır. Tarım arazileri ile köy dışındaki iş bölümünde ise tarım, hayvancılığa dayalı ekonomik değerlerden ve maddi nesnelerden faydalanılmıştır. Çalışmada köyün ekonomik yapısı (tarım, hayvancılık, zeytincilik vb.), köy ekonomisinin konut mimarisine etkileri (tipolojik farklar), köyün demografik yapısı, sosyal değişimlerin konut mimarisine etkisi değerlendirilmiştir. Köyün çevre yerleşmelerle ilişkisi, köyde zanaat veya el işleri, mekân içi ve mekân dışı mimari öğeler ışığında toplumsal cinsiyet rolleri, kadın ve erkek arasında mekân içi ve mekân dışı bağlamında tarımsal arazilerde ve köy dışında iş bölümü, ekonomide kadın ve erkeğin yeri göz önünde tutulmuştur.
Araştırma Makalesi

Geliş: 21.09 .2020

Kabul: 30.03.2021

Anahtar Kelimeler:

Troas,

Bozköy-Hanaytepe

Höyüğü,

Toplumsal Cinsiyet,

Etnoarkeoloji,

Mimari

\section{Gender Roles of Men and Women in Using Space in Bozköy: An Ethnoarchaeological Approach}

\begin{abstract}
Within the scope of the research, an ethnographic study was conducted to understand gender roles in Bozköy, in the Biga Peninsula (Troas) in Northwest Anatolia. The aim of the ethnographic study is to prepare ethnoarchaeological data on gender roles in the prehistoric period Bozköy-Hanaytepe Mound, which is planned to be excavated and explored in the future, and draw attention to gender roles. In the study, as a result of the impressions in Bozköy, gender roles are evaluated in the context of inside and outside space under the titles of private, public space and agricultural land. Architectural elements were widely used in interior and exterritorial work sections. Agricultural lands and economic values and material objects based on agriculture and animal husbandry were used in the business segment outside the village. In the study, the economic structure of the village (agriculture, animal husbandry, olive cultivation, etc.), the effects of the village economy on the housing architecture (typological differences), the demographic structure of the village, and the effects of social changes on housing architecture were evaluated. The relationship of the village with the surrounding settlements, crafts or handicrafts in the village, gender roles in the light of interior and exterritorial architectural elements, the division of labor between women and men in and outside the village in the context of indoor and outdoor work, the place of women and men in the economy are taken into consideration.
\end{abstract}

Research Article

Received: 21.09.2020

Accepted: 30.03.2021

Keywords:

Troas,

Bozköy-Hanaytepe

Mound,

Gender,

Etnoarchaeology,

Architecture.

\footnotetext{
* Doktora Öğrencisi, Çanakkale Onsekiz Mart Üniversitesi, Arkeoloji Anabilim Dalı, cevizlibar@gmail.com, ORCID ID: https://orcid.org/0000-0001-8342-261X
} 


\section{GíRIŞ}

Çalışmanın özüne geçmeden önce birbirlerinin yerine kullanılan bazı terimlerin aslında farklı anlamları olduğunu açıklamak gerekmektedir. Yunanca ě $\theta v o \varsigma$ ethnos $=$ halk / millet ve $\gamma \rho \alpha ́ \varphi \varepsilon ı v$ graphein = yazı kelimelerinden türeyen etnografya, yaşayan toplumları ve onların maddi kalıntılarını istatistiksel açıdan tanımlayan bir bilim olarak kabul edilmektedir. Hamit Zübeyr Koşay "Etnografya Folklor Dil Tarih v.d. Konularda Makaleler ve Incelemeler ${ }^{l}$ " adlı derleme eserinde etnografya için "halkın yaşayış tarzını tipik iptidai unsurlara inerek bütün teferruatı ile tasvir eder, konusu halkın maddi kültürüdür." tanımını yapmaktadır. Yunanca ethnos: halk / millet ve logos: bilim kelimelerinden türetilmiş olan etnoloji, farklı toplumların davranış biçimlerini, inançlarını ve folklorik özelliklerini sistemik karşılaştırmasını içeren antropolojinin alt bilim dalı olarak tanımlanmaktadır. Etnografyadan farkı etnolojinin daha bilimsel bir yaklaşıma sahip olmasıdır. Etnologlar, etnograflar tarafından toplanan verileri karşılaştırarak farklı kültürlerin zıt ve benzer özelliklerini bir araya getiririler. Koşay, folklor için “halkın yaşayış tarzında, tipik iptidai unsurları arayarak, nesilden nesile intikal eden yazısız manevi medeniyet hatıralarını toplar ve folklorun konusu halkın manevi kültürüüür ${ }^{2}$.” demektedir. Masal, müzik, dans, efsaneler, sözlü tarih, atasözleri, fikralar, halk inançları, gelenekler ve töreler gibi somut olmayan kültürel miras şeklindeki ifadeye folklor denilebilir. Folklor kültür üzerinde yoğunlaşır ve maddi kültür bazında temsil edilmeyen konuları çalışmaktadır. Araştırmanın temeli olan etnoarkeoloji genel manada arkeolojik amaçlar için insanların maddi kalıntıları üzerinde yoğunlaşarak onların etnografik açıdan incelenmesi olarak tanımlanabilir. Kültürden çok toplumun etnografik açıdan çalışılması esastır. Etnoarkeoloji ise eski yaşam biçimlerinin anlaşılması konusunda arkeologlara yardımcı olmaktadır. Eski çağlarda ve günümüzde benzer sosyo-ekonomik sistemlerde yaşayan toplumların karşılaştırılması etnoarkeoloji için önemli bir yöntemdir. Bu anlamda etnografya arkeologlara geçmişte insanların nasıl yaşadı̆̆ ve kültürün diğer konularını anlayabilme adına yeni bakış açıları sunabilmektedir ${ }^{3}$.

\section{ETNOARKEOLOJI}

Hamit Zübeyr Koşay etnoarkeolojinin tanımını “Archéocivilisation” ise arkeoloji ve din tarihi yardımı ile folklor malzemesini araştırır ve bunları diriltmeye ve izaha çalışır. Bu öteden beri bilinen “continuité” nin başka bir şekilde ifadesidir ${ }^{4}$ ” şeklinde yapmıştır. Etnoarkeoloji günümüzde, 1960'lı yıllarda Yeni (Süreçsel) arkeolojinin öncülerinden Lewis Binford'un 5 “materyal kültür bütün sistemin

\footnotetext{
${ }^{1}$ Koşay, 1974.

2 Koşay, 1974: 44.

${ }^{3}$ Takaoğlu, 2007a.

${ }^{4}$ Koşay, 1974: 199.

${ }^{5}$ Binford, 1962: 217.
} 
yapısı hakkında bilgi sunabilir” fikri ve "maddi kültür bir toplumun yapısını ve kültür davranışını ne dereceye kadar yansitabilir” sorusu ile Post-Süreçsel arkeolojinin kurucusu Ian Hodder öncülüğünde 1982 yılından itibaren tartışılmaya başlanmıştır ${ }^{6}$. Başka bir ifade ile maddi kalıntılar kültürü anlamak veya tanımak için ne kadar gerekliyse tek başlarına kültürü ifade etmek için yeterli olmayabilirler.

Etnoarkeoloji arkeoloji ve etnolojinin konuları üzerinde yoğunlaşmaktadır. Arkeolojik buluntular yoluyla insanların davranış biçimlerini anlamaya çalışan etnoarkeologlar, günümüzde hala yaşamakta olan ya da yakın zamana kadar yaşadıkları bilinen ve etnografik açıdan iyi incelenmiş toplulukların sahip oldukları sosyo-kültürel sistem içindeki davranışlarını yansıtan materyaller ile eski kültürler arasında çeşitli analojik yaklaşımlarda bulunarak hipotezlerini desteklemeye çalışırlar ${ }^{7}$. Etnoarkeolojinin teorik ve metotsal açıdan amaçları vardır. Metotsal açıdan etnografik veriler analoji (benzerlik kurma) yardımıyla arkeolojik amaçlar için geçmiş toplumları anlamak adına belli hipotezler ortaya atmak için kullanılır. Teorik açıdan ise insan davranışları ile bu davranışların insan maddi kültürünü ne şekilde etkilediği arasındaki ilişkiyi anlamak etnoarkeolojinin ana amacı sayılmaktadır.

\section{Türkiye'de Etnoarkeoloji Çalışmaları}

Türkiye'de etnoarkeolojik çalışmalar daha çok kırsal konut tipolojisi, kırsal yerleşim mantığ1 ile arkeolojik yerleşmelerin yorumu, sosyal ve ekonomik hayatın mimariye yansıması şeklinde karşımıza çıkmaktadır. Toplumsal cinsiyet rollerine dair etnoarkeolojik çalışmalar tercih edilmemiştir.

Türkiye'de 1930-1970 arasının etnoarkeoloji disiplinin gelişiminde önemli bir yeri vardır. Etnograf ve arkeolog Hamit Zübeyr Koşay’ın gerçekleştirdiği çalışmalar büyük önem taşımaktadır. Koşay’ın, Türk Tarih Kurumu adına gerçekleştirilen Alacahöyük kazıları sırasında Alaca köyünün etnografyasını derleyerek prehistorik Alacahöyük maddi kalıntılarını yorumlamaya çalışması öncü bir yaklaşım olarak kabul edilebilir. Bunun yanısıra Etnografya ve Folklor Kllavuzu ${ }^{8}$ adlı eserinde, ilkel toplumların geçmiş halklar konusunda sağlıklı bilgi verdiğini söylemiştir. Özellikle üretim ile ilgili konularda etnografik analojinin önemli bir yaklaşım olduğunu göstermiştir. Köy mimarisi, hasat ve hasatta kullanılan tarım aletleri, ilkel tarım yöntemleri, depolama, çanak çömlek üretimi gibi konularda yapılan etnografik çalışmaların prehistorik toplumları daha yakından tanımadaki önemi vurgulamıştır.

Alman Mimar Rudolf Naumann'ın 1955 yılında gerçekleştirdiği Architektur Kleinasiens (Eski Anadolu Mimarlı̆̆ı) adlı çalışma kayda değer önemli bir mimari çalışmadır . Modern Boğazköy yerleşimi köy mimarisini inceleyerek Hitit konut mimarisini daha iyi anlama çabası dikkat

\footnotetext{
${ }^{6}$ Hodder, 1982.

${ }^{7}$ David ve Karmer, 2001: 2.

${ }^{8}$ Koşay, 1939.

${ }^{9}$ Naumann, 1998.
} 
çekmektedir. Modern Boğazköy ile Hitit Boğazköy yerleşimi arasında plan özellikleri, kullanılan inşaat malzemeleri ve teknikleri açısından benzerlikler tespit edilmiştir ve bu benzerlikler Hitit ev mimarisinin bilinmeyen özellikleri konusunda destekleyici bakış açıları sunmuştur.

1960’lı yıllarda disiplinler arası çalışmaların gerekliliğini ortaya koyan Yeni (Süreçsel) arkeoloji kavramının Anadolu arkeolojisine dâhil olması etnoarkeoloji adına olumlu gelişmelere neden olmuştur. 1960'lı yıllarda Fransız prehistoryacısı J. Bordaz’ın taş teknolojisi üzerine gerçekleştirdiği çalışma ciddi anlamda ilk etnoarkeolojik araştırma niteliğindedir ${ }^{10} .1963$ yılında Chicago Üniversitesi “Oriental Institute” ile İstanbul Üniversitesi iş birliği sonucu gerçekleştirilen Güneydoğu Anadolu Ortak Prehistorya Projesi Yeni arkeoloji ilkelerinin Anadolu arkeolojisine dâhil olma sürecini hızlandırırken Robert J. Braidwood ile Halet Çambel önemli rol oynamıştır ${ }^{11}$.

Türkiye'de etnoarkeolojik çalışmaları 1968 yılına, Türkiye arkeolojisinde yeni bir dönemin başlangıcına götürmek gerekmektedir. Orta Doğu Teknik Üniversitesi’nin girişimi ve maddi desteğiyle yeni inşa edilmekte olan Keban Barajı'nın sular altında bırakacağı alanlarda kalacak eserler üzerinde uluslararası bir kurtarma projesi gerçekleştirilmiştir ${ }^{12}$. Türkiye'de 1968 - 1976 yılları arasında Keban Baraj Gölü Projesi bilim dünyası ve devletin ortak hareket etmesi ile gerçekleşmiş bir projedir. ODTÜ'den rektör Kemal Kurdaş'ın öncülügüunde İstanbul Üniversitesi'nden Halat Çambel'in büyük katkıları, Chicago Üniversitesi'nden Robert J. Braidwood ve Michigan Üniversitesi desteği ${ }^{13}$ ile kazı öncesinden itibaren farklı disiplinlerden uzmanların uyumlu çalışmları, arazi taramaları, anıtsal ve sivil mimari belgelemeleri ve kazı aşaması ile organize kurtarma projelerinin Türkiye ve dünyada ilk ve en başaralı örneklerinden birisi olarak kabul edilmektedir ${ }^{14}$. Özellikle Aşvan köyü ${ }^{15}$ ile Hamit Zübeyr Koşay’ın Pulur-Sakyol'daki etnografik çalışmaları önem kazanmıştır ${ }^{16}$

1970’li yıllar çanak çömlekçilik alanında pek çok etnoarkeolojik çalışmaya sahne olmuştur. C.N. Steele 1971 yılında Orta Anadolu'nun kuzey batısında Eskişehir ili Sorkun köyünde seramik üzerine bir etnoarkeolojik çalışma gerçekleştirirken ${ }^{17}$, H. Crane 1975 ve 1977 yılları arasında Manisa' da Sardis civarında Gökeyüp, Datbey ve Türkönü köylerinde geleneksel çanak-çömlek üretimi konusunda çalışmalar gerçekleştirmiştir ${ }^{18}$. Tomris Bakır tarafından 1978 yılında Erzurum'a bağlı Yiğittaşı

\footnotetext{
${ }^{10}$ Bordaz, 1965; 1969.

${ }^{11}$ Çambel vd., 1980.

12 Kalkan, 2009: 113.

${ }^{13}$ Arsebük, 1983: 70

14 Özdoğan 2011: 81-82

${ }^{15}$ Whallon ve Kantman, 1970: 4-5.

${ }^{16}$ Koşay, 1970: 139-172; Koşay, 1971: 99-101; Koşay, 1972: 127-132.

${ }^{17}$ Steele, 1971.

${ }^{18}$ Crane, 1988.
} 
köyünde yapılan çanak çömlek çalışması Anadolu etnoarkeolojisi için önemlidir. 1980'li yılların sonunda Elazığ'’n Uslu köyünde gerçekleştirilen çanak-çömlekçilik araştırması yöntemi açısından önemli bir yere sahiptir ${ }^{19}$. Bu çalışmalar sırasında elde edilen bilgiler çanak çömlek teknolojisi veya üretim zinciri konusunda bilgi vermelerinin yanı sıra çanak çömlek üretiminin gerçekleştiği sosyal ve kültürel ortamları anlamaya yönelik veriler de sunmaktadır.

Çanak çömleğin dışında mimaride önemli etnoarkeolojik çalışmalar gerçekleştirilmiştir. Özellikle Jak Yakar ve Lois Garzon tarafından 1970'li yılların başında Orta Karadeniz'de Samsun'da yapılan çalışma mimari alanda ilk etnoarkeolojik çalışmayı temsil etmektedir ${ }^{20}$. Özellikle modern köylerin yerel ahşap mimarisi ile İkiztepe kazıları Geç Kalkolitik ve Son Tunç Çağı mimarileri arasındaki bağlantı oldukça başarılı bir şekilde ortaya konulmuştur. Ardından Handan Alkım tarafindan yapılan mimari çalışma önemli bir adımı temsil eder ${ }^{21}$. Malatya Cafer Höyük’te 1979 ve 1986 yıllarında O. Aurenche tarafından Neolitik yerleşimin yanında yer alan modern köyde gerçekleştirilen çalışma mimari anlamda etnoarkeolojik çalışmalar arasında yer almaktadır ${ }^{22}$. Benzer şekilde M.R. Dittemore’un Bilecik yakınlarındaki Zemzemiye köyü mimarisi üzerine yaptığı etnoarkeolojik çalışma da bu kapsamda değerlendirilebilir ${ }^{23}$.

Anadolu etnoarkeolojisinin ihmal edilen konularından tarımın kökeni konusunda gerçekleştirilen paleoetnobotanik çalışmaların varlığı son derece önemlidir. Bu bağlamda ilk öncü çalışma Jack Harlan tarafından 1960'lı yılların sonunda Güneydoğu Anadolu Bölgesi’nde yabani bitkilerin ekim ve hasat süreçleri ile ilgili olarak yapılmıştır ${ }^{24}$. Benzer şekilde Füsun Ertuğ İç Anadolu'da çok önemli bir paleoetnobotanik çalışma gerçekleştirmiştir ${ }^{25}$. Ertuğ, Neolitik dönem Aşıklı Höyük’te benimsenmiş olabilecek bitki elde etme ve tarıma dayalı ekonominin özelliklerini anlamaya yönelik bir model oluşturmak için yerleşim yakınındaki köylerde araştırmalar yapmıştır. Yine Füsun Ertuğ tarafından yapılan ve tarımsal yaşam bünyesinde bitkileri öğütme, ezme ve işleyerek yiyecek hazırlama sürecinde kullanılan ögütme ve ezgi taşları üzerine yapılan çalışma Anadolu etnoarkeolojisi içinde türünün ilk örneğini oluşturmaktadır ${ }^{26}$.

Gordion Kazı Projesi 1994 yılından itibaren etnoarkeolojik çalışmalara yer vermektedir. Ayşe GürsanSalzmann tarafindan 2011 yılında yayınlanan "The Women of Yassıhöyük, Turkey: Changing Roles in

\footnotetext{
${ }^{19}$ Angle ve Dottarelli, 1990.

${ }^{20}$ Yakar ve Garzon, 1976.

${ }^{21}$ Alkim, 1983.

${ }^{22}$ Aurenche ve Calley, 1984; Aurenche vd., 1997.

${ }^{23}$ Dittemore, 1983.

${ }^{24}$ Harlan, 1967.

${ }^{25}$ Ertuğ, 1998.

${ }^{26}$ Ertuğ, 2002.
} 
a New Economy ${ }^{27}$ " makalesi, ekonominin değişmesi ile Yassıhöyük kadınlarının hane içi faaliyetlerine dair özel bir çalışmadır. Salzmann’a göre Türkiye son 50-60 yıl içinde özellikle Batı ve İç Anadolu anlamında çok değişmiştir. Geleneksel tarım metotları yerini makineli üretime bırakmıştır. Peki, önceden yüklenmiş belirli görevleri olan kadınlar değişen ekonomi ile toplumsal cinsiyet rolleri ve hane içi faaliyetler bağlamında neler yaşamaktadırlar? Salzmann gözlemleri ve sözlü mülakatları neticesinde değişen ekonomi ile hane içi (halkı) faaliyetleri bağlamında toplumsal cinsiyet rolleri üzerinde önemle durmuştur. Yassıhöyük Ankara'nın Polatlı ilçesinde yer almaktadır. Yassıhöyük, Ankara - Eskişehir demiryolu ve karayolu sayesinde doğu ile batı arasında önemli bir güzergâhta bulunur. Yassıhöyük’te 82 hanede 450 kişi yaşamaktadır. En kalabalık köyün 1.050 nüfusu bulunmaktadır. Tahıl ağırlıklı tarımla beraber küçükbaş ve büyükbaş hayvancılık yapılmaktadır. Dağınık yerleşim düzeni içinde akrabalar ve komşular birlikte çalışmaktadırlar. Evler genellikle kerpiçtendir. Evlere "hayat" denilen yerden girilmektedir. Hayat aynı zamanda yaz mevsiminde kadınların bir araya gelerek sosyalleştikleri yerdir. Erkekler sosyalleşmek için köy kahvesine gitmektedirler. Kamusal alanlar olarak cami, mezarlık, sokaklar ve yünlerin yıkandığı, hayvanların su içtiği köyün çeşmesi bulunmaktadır. Çalışmada köyün coğrafik konumundan, Yassıhöyük'ün kamusal ve özel mekânlarından bahsedilmiş, örnekler verilmiştir. Ayşe Gürsan-Salzmann köyden üç kadınla tarım, çobanlık hakkında konuşarak gözlemlerine sözlü referanslar eklemiştir. Ev içi faaliyetleri içindeki turşu hazırlama, ekmek yapma, sarma yaprağı ile dolma hazırlama, bahçe işlerindeki sebze meyve üretimi, ot yolma ve çapalama üzerine kadınların rollerini anlamaya çalışmıştır. Sözlü mülakat yöntemi ile elde edilen bilgilere çalışmasında yer vermiştir.

2000 y1lında Jak Yakar'in “Ethnoarchaeology of Anatolia Rural Socio-Economy in the Bronze and Iron Ages” adlı eseri sonraki yıllarda “Anadolu'nun Etnoarkeolojisi Tunç ve Demir Çağlarında Kırsal Kesimin Sosyo-Ekonomik Yapısı” adıyla Türkçe'ye çevrilmiştir ${ }^{28}$. Anadolu'daki kırsal toplulukların geçmişten günümüze süregelen yaşam biçimlerini ve geleneklerini, 21. yüzyılın başında kırsal coğrafyalarda yaşanan modernizme yenilebilecekleri fikriyle yaşam tarzları araştırılarak kayda geçirilmiştir. Fecri Polat tarafından hazırlanan “Doğu Anadolu Yayla Kültürü ve Yayla Mimarisi (Etnoarkeolojik Bir Bakış)” adlı çalışmada Doğu Anadolu'da MÖ II. binde yaşayan kültürleri etnoarkeolojik açıdan anlamak ve yorumlamak amacıyla, günümüz yaylacılık faaliyetleri ve yayla mimarisinde yaşanan değişim süreci incelenmiştir ${ }^{29}$. Özellikle MÖ II. binde, bölgede mimari açıdan yaşanan değişim sürecini anlamak amacıyla, farklı dönemlerde tamamen terk edilmiş günümüz

\footnotetext{
${ }^{27}$ Gürsan-Salzmann, 2011.

28 Jakar, 2007.

${ }^{29}$ Polat, 2013.
} 
yaylalarında yaşanan formasyon-transformasyon süreci incelenmiş farklı bir açıdan değerlendirilmiştir.

\section{Troas'ta Etnoarkeoloji Çalışmaları}

Troas'ta yaklaşık yirmi yıllık geçmiş zaman diliminde yapılmış etnoarkeolojik çalışmalar bulunmaktadır. Troia'da uzun yıllar çalışmış bilim insanları tarafından gerçekleştirilmiş çalışmaların Troas etnoarkeolojisi için mihenk taşı olma özelliği vardır. Geçmişe yönelik uygulamaların tartışıldığı, konut ve çiftlik mimarisindeki inşaat organizasyonu ile bireysel hanelerden, mevsimlik yerleşimden ve köyün terk sürecine dair Bayramiç’in kuzeybatısında günümüzde yerleşime sahne olmayan Işıklar köyü çalışmaları ${ }^{30}$ ve yine terk edilmiş yerleşim yerlerinden bir tanesi olan Darıköy ${ }^{31}$, geleneksel yöntemlerle çanak çömlek yapılan Akköy çalışmaları ${ }^{32}$, Ezine ve Bayramiç ilçe sınırlarındaki Gökçebayır, Pınarbaşı ve Kutluoba köylerindeki kireç ocaklarından çıkarılarak harç sıva olarak günümüzdeki kullanımına dair çalışmalar ${ }^{33}$ etnoarkeoloji metodolojisi açısından son derece mühimdir. Rüstem Aslan’ın Neolitik’ten “Tarihi Milli Park” sürecine dek Troia ve çevresindeki yerleşmeleri yüksek lisans tezinde etnoarkeolojik bakış açısıyla değerlendirmesi ${ }^{34}$ ve Troas'taki hızlı ekonomik gelişmelerin kırsal konut mimarisine olası olumsuz etkilerini belgelemek amacıyla yaptığı etnoarkeoloji çalışması ${ }^{35}$, bölgeye dair gerçekleştirilmiş önemli araştırmalardır. Bunların dışında konut tipolojisi ${ }^{36}$ ile zeytincilik ${ }^{37}$ konularında Troas etnoarkeolojisi ile ilgili yazılmış yüksek lisans tezleri de yer almaktadir.

Troas ve Bozcaada (Tenedos) bölgelerinde kırsal arazi kullanımı ve geçim ekonomisi konularında 2000 yıllarının başından itibaren kıymetli çalışmaları bulunan Turan Takaoğlu, bir araya getirdiği bilim insanlarının çalışmalarını derleyerek Türkiye etnoarkeolojisi için daha önce yapılmamış olan seri yayın dizisine imza atmıştır ${ }^{38}$. Çok önemli bir yere sahip bu çalışmalar Neolitik’ten günümüze olan zaman dilimi içerisinde, etnoarkeoloji disiplininin metodolojisi, analojisi ile problemlerine yer vermektedir. Köy mimarisi, kırsal arazi kullanımı ve yerleşim mantığı konularının yanı sıra aralarında Troas'ta sıkça görülen zeytincilik ve bağcılıkla beraber tarım ve hayvancılık gibi geçim ekonomileri kavramları üzerinde durulmuştur. Kişisel süs eşyası, hasır yaygı ile çanak ve çömlek yapımı

\footnotetext{
${ }^{30}$ Blum, 2000; 2003.

${ }^{31}$ Aslan ve Blum, 2004: 127-138.

32 Tekkök, 2000.

${ }^{33}$ Filgis vd., 2005.

${ }^{34}$ Aslan, 1997

${ }^{35}$ Aslan, 2011.

36 Akgün, 2010.

${ }^{37}$ Gürel, 2016

${ }^{38}$ Takaoğlu, 2004; 2005a; 2007b; 2008.
} 
bağlamında seramik atölyelerine dair çalışmalar çok değerlidir. Takaoğlu'nun çalışmalarına paralel olarak kıyı Troas'ta kırsal hayvancılık ve arazi kullanımı ile ilgili hayvan ağıllarını temel alan etnografik veriler sayesinde aynı coğrafya ve çevresel etkenlerle tarihöncesi toplulukların benzer arazi ve üretim teknikleri üzerine çalışmalar da eklenmiştir ${ }^{39}$.

Troas bölgesinde Neolitik Coşkuntepe ${ }^{40}$ gibi tarıma müsait olmayan engebeli arazilerde yer alan doğal tepeler üzerinde kurulmuş çok sayıdaki tarihöncesi yerleşimin tarım dışı alternatif stratejilerinin anlaşılması bakımından günümüz topluluklarının etnografik unsurlarının belgelenmesi gerekmektedir. Kalkolitik Gülpınar kazı sonuçları Troas bölgesinin kıyı köy topluluklarının varlığını sürdürdükleri dönemde nasıl bir yaşam biçimine sahip oldukları konusunda fikir vermektedir. Kazılarda ele geçen hayvan kemikleri, deniz kabukları, bitki kalıntıları, çanak çömlek parçaları ve üzerindeki negatif tekstil izleri ile çok sayıda iğ ve ağırşak, burada yasayanların balıkçılık, avcılık, tarım, hayvan besiciliği ve dokumacılığı kapsayan karma bir ekonomik sistemi benimsemiş olduklarını düşündürmektedir ${ }^{41}$. Kalkolitik dönem çanak çömleğin üzerindeki hasır izlerini konu edinen ve geleneksel hasır dokumacılığı konusunda bilgiler veren yüksek lisans sonrası çalışma ${ }^{42}$ ile Kalkolitik dönem deniz kabuklarına dair bir başka yüksek lisans sonrası çalışma ${ }^{43}$ sayesinde Çanakkale Troia Vakfı tarafından "Studies on the Troad” adıyla çıkan süreli yayınlarda etnoarkeolojik çalışmalara yer verilmiştir. Bahsi geçen çalışmalar arasında olan her iki çalışmada arkeolojik buluntuların niteliği toplumsal cinsiyet rolleri hakkında önemli ipuçları sunarken maalesef bu bağlamda bir görüş ortaya atılmamıştır. Toplumsal cinsiyet rollerine dair Coşkuntepe'de ve Gülpınar'da tespit edilmiş antropomorfik figürinler az da olsa ipuçları verebilmiştir ${ }^{44}$.

Troas’taki etnoarkeolojik çalışmalar sosyo-ekonomik veya kültürel sistemleri anlamaya yönelik olarak karşımıza çıkmamaktadır. Çanakkale Troia Vakfı tarafından "Studies on the Troad” adıyla "BozköyHanaytepe ve Çevresi Prehistorik Dönem Yüzey Araştırmaları "45 kitabında Rüstem Aslan ve Fecri Polat Bozköy-Hanaytepe Höyüğü'nün yakınındaki Bozköy’de etnografik çalışmalar başlatarak Bozköy-Hanaytepe Höyüğ̈̈'ne etnoarkeolojik veriler sunmayı amaçlamışlardır ${ }^{46}$.

\footnotetext{
39 Özdemir ve Bamyac1, 2019.

${ }^{40}$ Takaoğlu ve Özdemir, 2013a: 35

${ }^{41}$ Takaoğlu ve Özdemir, 2013b: 24

42 Özdemir, 2013.

43 Yavşan, 2013.

${ }^{44}$ Mutlu, 2017: 90-100.

${ }^{45}$ Aslan ve Polat, 2012.

${ }^{46}$ Polat vd., 2012.
} 
Troia Tarihi Milli Parkı ve çevresindeki köy halkı ile köylerin kuruluşuna yönelik içerisinde göç, demografik yapı, ekonomi, mimari, çevre, tarih ve etnografik çalışmalara yer veren kitaplar yayınlanmıştır. Bunların ilki “Halileli: Troia Ovası’nda Bir Köy”47 adlı çalışmadır. Troia antik kentinin hemen yanı başında Simois (Dümrek) nehrinin kenarında kurulmuş bir köy olan Halileli, Roma döneminden bugüne zaman zaman terk edilse de farklı grupların yerleşimine sahne olmuştur. Alüvyal dolgulu verimli tarım arazilerine sahip köyde, 1877-78 Osmanlı Rus Savaşı (93 Harbi) ile başlayıp son olarak 1950'li yıllardaki Balkan göçleri neticesinde göçmenler (muhacirler) ve manavlar (yerli halk) iskân etmektedir. İkinci çalışmada “Tevfikiye Köyü: Son Troialılar”48 adlı kitapta Troia'nın parçası haline gelmiş Tevfikiye ile Troia arasında bağ kurulmuştur. Tevfikiye köyünde 93 Harbi sonrası, 1923 ile 1930 yılında ve 1950-1951 göçleriyle gelen muhacirler yaşamaktadır. Troia'nın yanı başına Hisarlık Tepesi'ne yerleşmek stratejik bir tercihtir. Bataklık olan ovadan yüksek ve sineklerden uzak rüzgâr alan konumu ile Schliemann tarafından sürdürülen Troia kazılarında işçi olarak çalışabilmek muhacirlerin Hisarlık'1 seçmelerinde belirleyici olmuştur ${ }^{49}$. Dal örgü üzerine çamurla sıvanmış duvar ve üstü sazlardan oluşan yapılar inşa ederek yerleşen muhacirler yerli halkın (manav) yaşadığı Çıplak köyüne komşu olmuşlardır. İki komşu köy arasındaki arazi anlaşmazlıkları Çıplak köyüne bağlı Hisarlık'ın yeni bir isimle köy statüsüne bürünmesine vesile olmuştur. Padişah II. Abdulhamit'in yeğeni olan Şehzade İbrahim Tevfik Efendi, Tevfikiye köyüne ismini vermiştir. Üçüncü kitap ise "Yeniköy: Troia'nın İlk Savunma Hattı"50 olan Troia temalı bir başka araştırma çalışmasıdır. Yeniköy Ege Denizi ve adalara bakan düzlüğün üzerinde Beşik Koyu, Beşik-Yassıtepe ve Beşik-Sivritepe'nin yanında 1915 yılında Rumlar tarafından terk edilmiş ve 1951 yılında Bulgaristan göçmenleri tarafindan tekrar kurulmuştur.

\section{TOPLUMSAL CINSIYYET ARKEOLOJISI}

Toplumsal cinsiyet açısından arkeoloji, erkeklerle kadınların rollerini, faaliyetlerini, ideolojilerini, kimliklerini ve aralarındaki farkları inceleyen bir dal olarak ${ }^{51}$ 1970'li yıllarda çalışılmaya başlanmış ve 1980'li yıllar ile ivmelenerek günümüzde post-süreçsel arkeolojik yaklaşım içinde önemli bir yer edinmiştir. Toplumsal cinsiyet antropolojisine duyulan ihtiyaç dünyada gelişen kadın hareketi ile gündeme gelmesine rağmen toplumsal cinsiyet arkeolojisinin kendine yer edinmesi çok daha yavaş olmuştur. Eğitim, iş ve yükselme firsatlarının erkek emsalleriyle eşit olmadığını gören kadın arkeologların sayıca artması bu dalın yayılmasında etkili olmuştur. Durumu anlama ve belirtilen

\footnotetext{
${ }^{47}$ Polat ve Yeleş, 2017.

48 Polat, 2018a.

${ }^{49}$ Polat, 2018a.

${ }^{50}$ Polat, 2018b.

${ }^{51}$ Nelson, 2006: 1.
} 
konularda eşitlik arama sürecindeki kadınlar arkeoloji raporlarında geçmiş toplumlarda yaşamış kadınların neden ihmal edildiklerini ve küçümsendiklerini ya da neden özellikleri belirsiz bir kitleye topluca dahil edildiklerini soruşturmaya başlamışlardır.

Başlangıçta bütün arkeologlar tarafından ciddiye alınmasa da bazı alanlarda toplumsal cinsiyet konusu sıklıkla dile getirilir olmuştur. İlk insanlara ait fosilleri inceleyen kadınlar, insanın "avcı erkek" şeklindeki yaratılış modeline "toplayıcı kadını" modelini öne sürerek karşı çıkmışlardır. California Üniversitesi'nden Adrienne Zihlman ve Nancy Tanner bu doğrultudaki araştırmalara 1970'lerde başlamış olmalarına karşın arkeolojinin bütünü üstünde insan kalıntıları üzerinde durdukları kadar odaklanmamışlardır ${ }^{52}$. Tarihöncesi arkeologları tarafından yayınlanmış ilk makale Berkeley’deki California Üniversitesi'nden Margaret Conkey ile Minnesota Üniversitesi'nden Janet Spector tarafından ortak yazılmıştır ${ }^{53}$. Hem Yeni Dünya hem de Eski Dünya arkeolojisini birlikte temsil eden yazarların iddiaları oldukça güçlüdür; araştırmada toplumsal cinsiyet arkeolojisinin neden önemli olduğu ortaya konmakta, tanınmış çok sayıdaki arkeolojik kazı alanıyla ilgili yayında erkek egemen bakış açısına sahip olunmadığında bir başka ifadeyle toplumsal cinsiyete önem verildiğinde ne kadar farklı sonuçlar elde edilebileceğinin örnekleri verilmektedir. Daha sonraları toplantı ve konferanslar giderek artmış, Joan Gero ve Margaret Conkey'in düzenledikleri konferans sonunda Engendering Archaeology: Women in Prehistory adlı eser yayımlanmışıır ${ }^{54}$.

Toplumsal cinsiyet arkeolojisini pek çok farklı araştırma içerisinde görebilmek mümkündür. Örneğin Julia Hendon'ın Geç Klasik Dönem Maya uygarlığındaki hane halkı araştırmasıdır ${ }^{55}$. Aynı evde yaşayan insanları türdeş bir grup olarak ele almayıp cinsiyet, yaş ve statü farklarına göre değerlendiren Hendon, her bireyin farklı hedefleri olduğunu göstermiştir. Hane halkı ile devlet arasındaki ilişkiyi de ele alarak siyasi faaliyetin resmi olabileceği gibi gayri resmi de olduğunu hem erkeklerin hem de kadınların hane ile devlet arasında arabuluculuk bağlamında etkin rollere sahip olduklarını ortaya koymuştur. Janet Levy ${ }^{56}$ ise Danimarka'nın Tunç Çağı metallerini ve simgelerini ele almış hem kullanılan metal çeşitlerinde hem de bunların bulundukları yerlerde toplumsal cinsiyete göre değişen farklar olduğunu göstermiştir. Ortaya koyduğu toplumsal cinsiyet farkları karmaşık toplumlar açısından büyük önem taşımaktadır. Türkiye'de toplumsal cinsiyet arkeolojisine dair İç Anadolu Bölgesi’nde bulunan Boncuklu Höyük, Çatalhöyük, Aşılı Höyük ve Köşk Höyük yerleşmelerinin

\footnotetext{
52 Taner ve Zihlman 1976: 587

${ }^{53}$ Conkey ve Spector, 1984: 1-38.

${ }^{54}$ Wylie, 1997: 89.

${ }^{55}$ Hendon, 2000: 299-301.

56 1981: 179-187.
} 
MÖ 8500-5000 yıllarına tarihli Neolitik Çağ başından İlk Kalkolitik Çağ'ın sonuna kadar toplumsal cinsiyet rollerinin nasıl değiştiğini araştıran çalışma son derece önemlidir ${ }^{57}$. Mezarlar, mezar hediyeleri, iskeletler, ölü gömme gelenekleri ile antropomorfik nesneler gibi farklı verilerden yararlanarak oluşturulan çalışmada cinsiyet açısından eşitlik dikkat çekmektedir. İç Anadolu ile ilgili diğer araştırma Neolitik Çağ Aşıklı Höyük kişisel süs eşyalarının kullanımının toplumsal cinsiyet rollerini hangi ölçekte yansıttığını araştıran çalışmadır ${ }^{58}$. Takı kullanımında cinsiyetler arasında farklılıklar veya benzerlikler topluluk içerisinde bireylerin sahip olduğu toplumsal cinsiyet rollerinin anlaşılmasında yardımcı olabilmektedir. Aşıklı Höyük'te bulunan kişisel süs eşyalarının yaş ve cinsiyete göre dağılım analizleri farklı yaş ve cinsiyet gruplarından bireyler arasında farklı hammadde, tip ve renkte boncuk kullanımında ayrım olmadığını ortaya koymuştur. Farklı bir bölgeden bir başka çalışmada Batı Anadolu'daki Neolitik ve Kalkolitik Çağ yerleşmelerinin antropomorfik figürinler bağlamında toplumsal cinsiyet rollerinin sembolizmle beraber tartışmaya açıldığı görülmektedir ${ }^{59}$. ̇̇lk Tunç Çağı Ege dünyasının toplumsal cinsiyet rollerini mezarlar, antropomorfik nesneler, tavalar, ağırşaklar ve cinsel objeler sayesinde aktaran bir diğer araştırma Batı Anadolu, Ege adaları ile Yunanistan'daki verileri değerlendirerek İlk Tunç Çağı'nda kadınlar ve erkekler arasında üretim etkinlikleri, beslenme alışkanlıkları ve sosyal statü ile toplumsal cinsiyet rolleri açısından eşitlik olduğunu saptamıştır ${ }^{60}$.

Toplumsal cinsiyetin arkeolojik yöntem ve kuramlar üzerinde karmaşık ama giderek artan bir etkisi vardır. Post-Süreçsel arkeolojinin yöntem ve hedefleriyle oldukça uyumludur ve Batı ülkelerinde destek bulmaktadır. Süreçsel arkeoloji ise toplumsal cinsiyetle pek ilgilenmemiştir; çünkü toplumsal cinsiyet ve öteki toplumsal değişkenler gündemine uygun değildir. Süreçsel arkeoloji kültürlerin kurucu parçalarını birbirleriyle yarışan ya da birbirlerine uymayan hedefleri olan bölümler olarak okumaktan çok uyumlu olarak ele alır. Oysa toplumsal cinsiyet çok katı süreçselcilerin bile yolunu açmıştır. Amerika'nın güneybatısı üzerine çalışan arkeolog Michele Hegmon "süreçsel artılar" olarak adlandırdığı başlıklar altında toplumsal cinsiyeti de saymıştır ${ }^{61}$

Sonuç olarak toplumsal cinsiyet, arkeolojinin bütün kollarında bakış açılarını değiştiren bir unsur olmuştur. Toplumsal cinsiyet arkeolojisi hane içindeki insan davranışlarının, düşüncelerinin ve sosyal organizasyonların oluş biçimlerinden faydalanmalıdır. Hane halkında doğumlar, ölümler, evlilikler,

\footnotetext{
57 Arslan, 2015.

58 Yelözer, 2016.

${ }^{59}$ Mutlu, 2017.

${ }^{60}$ Sezgin, 2019.

${ }^{61}$ Moss, 2005: 582-586.
} 
bölünmeler, ayrılmalar yaşanmaktadır ${ }^{62}$. Durağan olmayan hareketli yaşam toplumsal cinsiyet arkeolojisi için önemlidir. Toplumsal cinsiyet arkeolojisi prehistorik dönem araştırmalarında etnoarkeolojiden yararlanmaktadır. Etnoarkeolojinin üzerinde durduğu kırsal köy mimarilerinden ve tarım hayvancılık gibi geçim ekonomilerinden çokça faydalanmaktadır. Toplumsal cinsiyet arkeolojisinin ülkemizde çok az çalışılması; erkeklerle kadınlara gösterilen arkeolojik ilginin dengelenmesini, erkeklerin faaliyetlerine olduğu kadar kadınların faaliyetlerine de önem verilmesini sağlamak ve bütün kültürlerde kadının aynı olmadığını, karşılaştırmalı incelemeler yaparken kadın faaliyetlerine ayrı bir ilgi gösterilmesi gerektiğini dolayısıyla arkeolojinin yalnızca kalıntılarla değil ${ }^{63}$, insanlarla ilgili bilim olduğunu hatırlamak ve hatırlatmakta fayda vardır.

\section{BOZKÖY-HANAYTEPE HÖYÜĞÜ}

Bozköy-Hanaytepe Höyügü, Çanakkale'nin yaklaşı $50 \mathrm{~km}$ güneyinde Geyikli beldesinin $5 \mathrm{~km}$ kuzeydoğusunda Bozköy’ün 2 km güneyinde zeytin ağaçlarının arasında yer almaktadır (Har. 1). Höyüğün batısında Ege Denizi ile Bozcaada, doğusunda Mecidiye (Aktepe) ve Fığlı Dağı, güneydoğusunda kireç ocaklarının olduğu Gökçebayır (Bergaz) bulunmaktadır ${ }^{64}$.

2009-2011 yılları arasında Rüstem Aslan başkanlığındaki ekip tarafından gerçekleştirilen yüzey araştırmalarında Bozköy-Hanaytepe Höyüğü’nde el yapımı çanak çömleğe ait ağız kenar parçaları, açkı bezemeli çanak çömlekler, Troas, Doğu Ege adaları ve Batı Anadolu kıyı yerleşmelerinden bilinen cheese-pot kaplarına rastlanmıştır. Kazıyıcı aletler, öğütme taşları, işlenmiş kemikler, taş baltalar, baskı mühürler, deniz kabukları ile tespit edilen mermerden Kilia figürin ve İlk Tunç Çağı (İTÇ) idolleri sayesinde Troia I öncesi MÖ 4. binden başlayarak Son Kalkolitik Çağ’a tarihlendiği ve onun üstünde Troia I yerleşmesi ile Son Tunç Çağı (Troia VI) yerleşmesinin üstte yer aldığı anlaşılmıştır ${ }^{65}$. Bozköy-Hanaytepe prehistorik dönem kıyı çizgisinde iskân görmüş, bu açıdan Ege Gübre ve Yenikapı Neolitik Dönem yerleşmeleri ile kıyı yerleşmesi bağlamında benzer özelliklere sahiptir.

Bozköy-Hanaytepe Höyüğü, Batı Anadolu, Doğu Ege adaları, Kıta Yunanistan, Kiklad adaları ve Balkanlar'daki çeşitli yerleşimlerde stratigrafik olarak ele geçmiş buluntular ile ilişkilidir ${ }^{66}$. Troas'taki yüzey araştırmalarında hem malzeme yoğunluğu hem de yüzölçümü bakımından Troia dışında önemli bir yerleşimin Bozköy-Hanaytepe Höyüğü olabileceği düşünülmektedir.

\footnotetext{
${ }^{62}$ Çevik, 2009: 39.

${ }^{63}$ Nelson, 2006: 2

${ }^{64}$ Aslan vd., 2011: Res. 1.

${ }^{65}$ Aslan vd., 2011: 294; Y1lmaz, 2013.

66 Y1lmaz, 2013: 858.
} 


\section{BOZKÖY VE ÇEVRESİ}

Bozköy köyü Çanakkale il merkezinin 50 km güneyinde Geyikli beldesinin 5 km kuzeydoğusunda yer almaktadır (Har. 1). Bozköy içinde araştırma konusunu içeren Bozköy-Hanaytepe Höyüğü ise köyün 2 km güneyinde yer almaktadır (Res. 1). Höyüğün batısında Ege Denizi ve Bozcaada, doğusunda Mecidiye (Aktepe) ve Bozköy halkı tarafından kadim dağ olarak adlandırılan Fiğlı Dağı, güneydoğusunda kireç ocakları ile bilinen Gökçebayır (Bergaz) bulunmaktadır. Köyün güneybatısından Kemer Deresi akmaktadır. Açık havalarda Bozcaada ve Geyikli feribot iskelesi höyükten rahatlıkla görülebilmektedir.

Günümüzde zeytincilik Bozköy için ana geçim kaynağıdır. Bozköy'ün güneydoğusunda yer alan Darıköy, yöredeki en eski zeytin üretim fabrikasına sahiptir. Güneydoğusunda kireç ocakları ile bilinen Gökçebayır'ın (Bergaz) Kemallı köyü Bozköy'den önce, Mecidiye (Aktepe) köyü ise Bozköy ile zeytinciliğe başlamıştır. Bozköy'de zeytin hasat dönemi ekim, kasım, aralık aylarında çoğunluğu kadınlardan oluşan Bayramiç köylerinden çalışmaya gelen mevsimlik işçilerdir. Bozköy'ün batısında yer alan Çamoba köyünde karma tarım ekonomisi ve balıkçılık yapılmaktadır. Üvecik ve Mahmudiye'de ise zeytincilik Bozköy'e nazaran daha az gelişmiş, bunun yerine sulu tarım yapılmaktadır. Bölgede Yörükler, Manavlar, Türkmenler ve Muhacirler olmak üzere dört ana grup yaşamaktadır.

Bozköy'ün 25 km doğusundaki Akköy, antik dönemlerden bugüne dek çanak çömlek üretim merkezi olarak bilinmektedir. Bozköy halkı Akköy testilerini kullanmıştır ${ }^{67}$. Akköy testileri her yıl geleneksel olarak kurulan Ezine Panayırı'ndan temin edilmekle birlikte, özellikle 1955 yılı öncesinde deve sırtlarında köy köy gezerek Bozköy'e erkek tüccarlarca getirilir ve Bozköy erkekleri tarafından satın alınmıştır. 1970'li yıllarda Gökçebayır köyünde yağlı güreşler düzenlenmiştir. Çevre köylerin bir araya gelerek büyük bir sosyal organizasyona dönüşen güreşlerin düzenlenmesinde erkekler etkin rol oynamıştır. Sosyal organizasyon aynı zamanda ekonomik faaliyetler için fırsat sunmaktadır. Erkekler tarafından kurulan yiyecek içecek tezgâhları sayesinde önemli ekonomik kazanç elde edilmiştir. Yağlı güreşler dışında Geyikli'de deve güreşleri düzenlenmiştir. Aydın'dan gelen develer ile sahipleri hafta sonları sosyal ve kültürel organizasyonda boy göstermişlerdir. Bozköy erkekleri ve kadınları izleyici olarak katılmışlardır. Güreşlerin düzenlemesini, tezgâhlarının kurulup yiyecek içecek satılmasını, alanın toparlanmasını erkekler organize etmişlerdir.

${ }^{67}$ Tekkök, 2000: 100 
2018 yılında Çanakkale Tarih ve Kültür Vakfı (ÇATKAV) ile Çanakkale Troia Vakfı işbirliği sayesinde hayata geçirilen Troia'dan Assos'a uzanan arkeoloji, tarih, kültürel ve doğal değerleri içeren uluslararası standartta 120 km uzunluğundaki Troya Kültür Rotası, başlangıcından itibaren 2020 yılında ortaya çıkan Covid-19 virüsünün yol açtığı salgına rağmen ilgi görmeye devam etmiştir. Zeytincilik, kırsal mimari, tarih ve arkeolojik değerlerin bir arada olduğu "yerel miras" adıyla anılan Bozköy, rotanın önemli bir yerinde durmaktadır. 1530 Osmanlı dönemi haritalarında yer alan eski bir Türk köyü ve prehistorik Bozköy-Hanaytepe Höyüğü sayesinde, Bozköy ilgi çekici hale gelmektedir. Keşfetme merakı ile yola çıkan gezginler Bozköy’ün kültürel zenginliğini bire bir yaşama şansı bulabilmektedirler.

\section{Bozköy'ün Demografik Yapısı}

2013 yılında köyde yaşayan kadın erkek sayısı, medeni durum, öğrenim durumu gibi köy muhtarı Yahya Üner tarafından resmi olmayan bilgiler şeklinde alınmıştır. 2013 yılının kasım ayında köyde (mahallede) yaklaşık 80 ev ve yaklaşık 80 kişi kayıtlıdır; ancak kayıtlı kişi sayısının yarısı kadarı daimî ikamet etmektedir. Köy yıllar içinde göç vermiştir. Yakınındaki Geyikli’ye, Çanakkale’ye ve İstanbul'a göç eden insanlar zeytin hasadında köye gelmektedirler. Ortalama ömür kadınlarda 90, erkeklerde 85 yaştır. 2020 yılı içerisinde ilköğretim veya lise çağında kimse yoktur. Köy meydanını gören yerde 1990 yılında açılan okul taşımalı eğitim sistemi ile 2000'li yılların başında kapanmıştır. Bozköy’de doktorun olmadığı cumhuriyetin ilk yıllarından 1970'li yıllara kadar daha önce doğum görmüş, doğumda bulunmuş deneyimli yaşlı kadınlar köy ebeleri olarak gönüllü hizmet vermişlerdir. Bugün doğum oranı azalmış olsa da doğum Ezine veya Çanakkale' de gerçekleşmektedir. Günümüzde yetişkin ve yaşlı nüfus oranı yüksektir. 2020 yılındaki köy muhtarı Cavit Tuğral ve TÜíK nüfus veri tabanından alınan bilgilere göre Bozköy’de 2017-2020 yılları arasındaki nüfus dağılımı şu şekildedir (Tablo 1):

Tablo 1. Bozköy’ün 2017-2020 yılları arasındaki nüfus dağılımı (Bozköy Muhtarlığı ve TÜIKK).

\begin{tabular}{|c|c|c|c|}
\hline YIL & $\begin{array}{c}\text { TOPLAM } \\
\text { NÜFUS }\end{array}$ & $\begin{array}{c}\text { KADIN NÜFUSU ve } \\
\text { TOPLAM NÜFUSA ORANI }\end{array}$ & $\begin{array}{c}\text { ERKEK NÜFUSU ve } \\
\text { TOPLAM NÜFUSA ORANI }\end{array}$ \\
\hline 2020 & 73 & $39-\% 53.42$ & $34-\% 46.58$ \\
\hline 2019 & 80 & $45-\% 56.25$ & $35-\% 43.75$ \\
\hline 2018 & 89 & $49-\% 55.05$ & $40-\% 44.95$ \\
\hline 2017 & 88 & $50-\% 56.82$ & $38-\% 43.18$ \\
\hline
\end{tabular}


Bozköy’de yaşayan yerleşikler (manav) ve muhacirler (göçmenler) bulunmaktadır. Köy yerleşik (manav) köyü olmasına karşın 1934 yılında çıkarılan 2510 Sayılı İskân Kanunu sonrası köye göçmenler yerleştirilmiştir. Çevrede yaşayan Türkmenler ve Yörükler olmasına rağmen Bozköy'de sadece iki grup yaşamaktadır ${ }^{68}$. Köye sonradan yerleşmiş olan göçmenler Türkmen ve Yörük köylerine yerleşmemişler ya kendi köylerini kurmuşlardır ya da yerleşiklerin (manav) köyüne gelmişlerdir. İntepe ile Halileli gibi köylerin dışında Rumların evlerinde de oturmayan göçmenler mevcut ekonomik sistemi ve buna bağlı mimari yapının değişmesine neden olmuşlardır ${ }^{69}$. Bozköy'de ilk yerleşik aileler arasında Yetimler, Kulinler, Kocamanlar, Dubacılar, Danacılar, Çolak Kadirler, Karadayılar, Hüseyin Çavuşlar ve Hacı Yahyalar bulunmaktadır. Bugün bu ailelerin çocukları veya torunlarına ait mimari öğeler köyde bulunmaktadır.

\section{Bozköy Ekonomisi}

Bozköy köyü, belirli bir ekonomik seviyeye ulaşması nedeniyle 1930'larda vergi veren bir köy haline gelmiştir $^{70}$. Bozköy 1970'li yıllara kadar kısmen, 1955’ten önce tamamen zeytincilik dış1 geçim kaynaklarına sahiptir. Birincisi hayvancılık, ikincisi ise sulu tarım dışı ekip biçmeye bağlı buğday, arpa, bakla, nohut, susam, ayçiçeği, mercimek, yulaf, gibi tarım ürünleridir. Köydeki arazilerde meyve ve sebze yetiştirilmekte, ekonomik kazançtan ziyade ev içi tüketimine yöneliktir. Evlerin bahçesinde veya köyün yakınındaki bahçelerde sadece ailenin ihtiyacı kadar ıspanak, marul, domates, biber, patlıcan, nane, dereotu, maydonoz, soğan, sarımsak vb. ekilir. İhtiyaç duyulduğunda sebzeler taşıma suyu ile sulanmıştır.

1934 yılında mübadele anlaşmaları ile muhacirler köye yerleşmiştir. Muhacirlerin köye göç etmesi ile tarım ve hayvancılığa dayanan ekonomik sistemde farklılık yaşanmaya başlanmıştır. Köye ilk zeytin ağacı komşu köy Mecidiye (Aktepe)'den Yetimler sülalesine damat olarak gelen muhacir Sabri Sezgin ve bir başka muhacir Ahmet Ubay’ın katkıları ile gelmektedir. Bozköy’e yaklaşık 10 km uzaklıktaki kadim dağ Fı̆̆lı Dağı'ndan getirdikleri delice (anaç) zeytinin aşılanması ile köy toprakları zeytinle tanışmıştır. Muhacirlerle beraber yerleşik (manav) halktan özellikle Esat Erten, Tevfik Erten ve Ahmet Şen gibi kişiler ölmez ağaç zeytinin Bozköy’deki bugünkü verimli haline büyük emek vermişlerdir. 1960'lı yıllarda ilk fidanlar dikilerek 1970'li yıllarda ürün alınmıştır ${ }^{71}$. Zeytin sayesinde 1974 yılında ilk zeytinyağı fabrikası kurulmasına karşın, bu fabrika bugün kullanılmamaktadır (Res. 2-3). Günümüzde zeytincilik köy halkının ana geçim kaynağıdır. Hayvancılığa dayalı ekonomik sistemin

\footnotetext{
${ }^{68}$ Polat vd., 2012: 120.

${ }^{69}$ Polat vd., 2012: 125.

${ }^{70}$ Polat vd., 2012: 124

${ }^{71}$ Polat vd., 2012: 124.
} 
birdenbire yıkılıp yerine kolaylıkla zeytinciliğin tercih edildiğini nasıl söylemek mümkün değilse değişkenlik gösteren ekonomik sistemlerin benzerini Bozköy-Hanaytepe Höyüğü için de düşünmek gerekmektedir $^{72}$

Hayvancılığın ve zeytinciliğin dışında Bozköy'de meşe ağacının palamudu ekonomik değere sahiptir. Palamut boya sanayinde kullanılmak üzere Çanakkale'deki tüccarlara satılmıştır. Çanakkale'nin merkezinde Sarıçay'ın kenarındaki palamut depoları işlevini kaybetmiş, günümüzde kültür-sanat mekânı olarak kullanılmaktadır (Res. 4).

Hayvancılık, zeytincilik veya boya yapımında kullanılan meşe palamudu dışında 1970'li yıllarda değiş̧ tokuş yapılmıştır. Bozköy halkı zeytinyağı, ceviz karşılığında Bayramiç köylerinden pekmez veya peynir almışlardır. Değiş tokuşa dayalı ekonomik anlayışın yakın geçmiş zamana kadar işlediği düşünüldüğünde Bozköy-Hanaytepe yerleşimi için bu sistemi göz ardı etmek mümkün değildir.

Hayvancılıktan zeytinciliğe geçiş sürecinde koşullara uyum sağlayamayan ekonomik durumu kötüleşen aileler 1960'ların sonlarında büyük şehirlere göç etmiştir. 1970'li yıllarla birlikte köyde zeytinden ekonomik kazanç sağlanması ile mevsimsel göçler görülmüştür ${ }^{73}$. Zeytin toplamak için çevre ilçelerden gelip bir süre Bozköy'de kalan işçiler olduğu gibi Geyikli'ye taşınmış bir kısım Bozköylünün sabahları köylerindeki tarım arazilerine gelip akşam evlerine döndükleri bilinmektedir. 2016 yılında kurulan ve Bozköylü 35 kişiyi bünyesinde barındıran Bozköy Tarımsal Kalkınma Kooperatifi 2020 yılının sonbaharında komşu Çamoba köyünden salça yapmak için domates, biber satın almıştır. Köyün kadınları ve erkekleri ortak hareket ederek açık alanda, açık ateş üzerinde kazanlarda salça kaynatılmıştır. Pişirilen salçalar dinlendirilerek etiketli kavanozlara konulmuş ve salçalar köye gelen misafirlere satılmıştır. İlerleyen zamanlarda ortak sayısındaki artış ve beraberindeki kolektif üretim sayesinde köyün geçim kaynaklarında çeşitlilik ve verimlilik artması beklenmektedir.

2018 yılında hayata geçen Troya Kültür Rotası'na dahil edilen Bozköy'de gezginler için elektik ve suyu olan çadır kamp yeri bulunmaktadır. Gezginlerin yemek ihtiyaçları köyün kadınları tarafından cüzi meblağlar karşılığında yöresel ürünlerle karşılanmaktadır. Köyün erkekleri tarafından konaklayanlar için inşa edilmiş tuvalet ve banyo vardır. Salgın sonrası hayatın normale dönmesi ile gezginlerin Bozköy’de konaklama ve yemek ihtiyaçlarını karşılayacakları mekânlar hizmete girerek köyün ana geçim kaynaklarına zeytin dışında turizmin eklenmesi beklenmektedir

\footnotetext{
72 Polat vd., 2012: 129.

${ }^{73}$ Polat vd., 2012: 125.
} 


\section{Bozköy Mimarisi}

1960'lı yılların başlarında muhacirlerin sayesinde başlatılan zeytincilik faaliyetleri, hayvancılığa göre daha fazla ekonomik kazanç sağlarken kadın ve erkek arasında iş bölümleri yeniden belirlenmiştir. Artı değerin düşük olduğu 1955 yılı öncesinde hayvancılık döneminde kadın ile erkeğin günlük iş paylaşımında keskin bir ayrım görülmemektedir. Yaşamın devamı için beraber çalışmak, üretmek ve tüketmek zorunda olan kadın ve erkek, artı değerin büyümesi ve konut yapılarındaki gelişmeye paralel olarak iş bölümünde farklılıklara gitmişlerdir. Geçim kaynağındaki dönüşüm sayesinde kadının rolü artarken mimarideki değişiklikler kadının isteğine göre şekillenmiştir. Zeytin ve zeytinyağının depolanacağı alanlar ve ambar kadının tercihine göre belirlenmiştir. 1970'li yıllarla beraber cinsiyete dayalı iş bölümü tarım toprağında hasat öncesi başlar, hasat zamanı devam eder, mekân içi ve mekân dışında son bulmaktadır. Fidan olan zeytin mekânda son olarak salamura, çizik ve yağlık olmak üzere üç bölüme ayrılmaktadır. Salamura ve çizik zeytin sofralık, yağlık ise zeytinyağı olarak tüketime hazırlanmaktadır.

Ekonominin zeytinciliğe dönüşmesi ile 1955 yılı öncesi hayvancılık döneminde kullanılan yapıların işlevsel açıdan değiştiği görülmüştür. Özellikle avluda büyük değişimler olmuştur. Mevsimlik işçilerin kalabilecekleri odalar, zeytin ve zeytinyağının depolanacağı yerler inşa edilmiştir. Bunun dışında çatı sistemi değişmiştir. Hayvancılığın yapıldığı 1955 yılından önce ayçekirdeği sapı, çamur sıva, ereşte denilen deniz yosunu ve kil kullanarak yapılan düz dam evlerin yerine 1960 yılı sonrasında makas sistemli kiremit çatıya geçilmiştir. Artan nüfusla birlikte köye gelen misafir sayısının artması neticesinde misafir odası ihtiyacı doğmuştur. "Gizlence odası" olarak adlandırılan bu mekânlar sadece misafirlere özel odalardır ve diğer odalarla bağlantılı değildir. Geleneksel ev tiplerinin dışında açık sofalı iki odalı İzmir tipi ev, zenginliğin göstergesi iki katlı hanay tarzı ev ve alt katları kiler veya depo olarak kullanılan karnıyarık tipi ev planları gelişmiştir ${ }^{74}$. Büyük evlerde iç ve dış avlu olmak üzere iki avlu bulunurken, daha küçük evlerde sadece dış avlu yer almaktadır. Avlular kapı ve yüksek dış duvar ile sınırlandırılırken, avlular sokağa açılmaktadır. Ev dışı öğelerden dış avlunun çevre duvarının yüksek olduğu düşünüldüğünde özel mülk anlayışının getirdiği mahremiyet neticesinde hane halkı ile kamusal alan birbirinden ayrılmaktadır. Hane halkından kastedilen kadının kamusal alandan uzak tutularak mahremiyet düşüncesinin nesilden nesle aktarılarak tüm köyde uygulanabilirliğini göstermektir (Res. 6). Ailelerin büyümesi ile evler de büyümüştür. Ancak evli iki kardeşin aynı evde yaşadığ1 görülmemiştir. Onun yerine avlu kenarlarına başka evler inşa edilmiştir.

${ }^{74}$ Polat vd., 2012: 126. 
1934 y1lında muhacirlerin köye gelmesi ile gerek sosyal yaşamda gerekse mimaride değişimler yaşanmıştır. Muhacirlerden önce yerleşik (manav) köylülerin yaptıkları evlerde taş ve tuğla kullanımı zengin evini işaret ederken, kerpiç fakir evlerde kullanılmıştır. Su basmanı yüksek ev yapmak gücün ve zenginliğin göstergesidir. Ancak muhacirlerle beraber kerpiç kullanımında artış görülmüştür. Muhacirlerin gelmesi ile artan nüfus için meydan oluşturulmuş ve bu meydanın etrafında kamusal binalar inşa edilmiştir. Köy okulu, kahvehaneler meydanı görecek şekilde konumlanmıştır. Kahvehanelerde ortak kullanım alanının dışında genç erkekler için "gençlik odası" denilen ayrı bir oda bulunmaktadır. Muhacirlerin köye gelişi ile sokak yapısında da değişimler görülmüştür. Daha geniş ve uzun sokaklar oluşturulmuş, bazı sokaklar herhangi bir yere bağlanmadan sona erdirilmiştir. Kamusal alandaki değişimlerin yanı sıra sivil mimaride de değişimler görülmektedir.

Bahçe içinde zeytin, zeytinyağı depoları, kilerler, sundurmalar bağımsız yapı şeklindedir. Tuvalet evin dışında ve bahçenin uzak köşesinde konumlanmıştır. Bahçede yemek pişirmek için fırın kurulmuştur. Büyük evlerin büyük bahçelerinde süslü bitkiler ve meyve ağaçları dikilmiştir.

\section{ÖZEL VE KAMUSAL ALANDA TOPLUMSAL CINSIYYET ROLLERİ}

Mekân sadece odadan veya evden ibaret değildir. İçinde yaşanan çevre, yaşam biçimi, insan davranışlarının gerek tek başına gerekse başkaları ile veya farklı canlılarla ve çeşitli nesnelerle buluştuğu her türlü yer mekân şeklinde algılanabilir. Kadınların hayatlarını hangi yollarla değiştirmeye ve yeniden üretmeye giriştiklerini, ellerindeki kısıtlı imkânlarla hem kendilerini hem de ailelerini nasıl var edebildiklerini, sınırları olan ve olmayan mekânlarda kendilerini nasıl ifade ettiklerini anlama çabası önemlidir. Cinsiyet rollerine dayanan iş bölümü, farklı iktidar ve otorite ilişkileri bunlara göre oluşturulmuş alanlar yaratır. Kadın ve erkek arasında roller bakımından mekânsal ayrışma belirgindir. Mekân özel ve kamusal alan biçiminde ayrıştırılmış veya farklılaştırılmıştır. Kadınların yaşamı ev içi ile sınırlandırılmış, kamusal alanlara girişi denetim altına alınmıştır. Kimi kamusal alanlara ne zaman ve hangi kıyafetle gireceği belli kurallara bağlanmıştır ${ }^{75}$. Erkek ise kamusal alanın hakimi konumunda olmakla birlikte iktidar ve otorite tarafindan desteklenmektedir.

\section{Özel Alanda Toplumsal Cinsiyet Rolleri}

Özel alan tanımı ev içi, evin dışındaki avlu, bahçe, depolama alanları veya ahır gibi mekân içi öğeler için kullanılmaktadır. Mekân içi mimari öğeler 1şığında günümüz Bozköy’de kadın ve erkeğin mekân içi bölümlerde rolleri belirgindir. Ev içlerinde kadının tüm işleri üstlendiği, erkeğinse avlu gibi açık mekânlarla depolama yerlerinde roller üstlendiği görülmektedir. Çalışmada ev içinde toplumsal

${ }^{75}$ Çakır, 2010: 136. 
cinsiyet rolleri mutfak, hamam, oturma ve misafir odaları bağlamında değerlendirilirken, yıllık ve günlük işlerden yola çıkarak kadın ve erkeğin belirgin rolleri üzerinde durulmaya çalışılacaktır.

\section{Ev içinde toplumsal cinsiyet rolleri}

Bozköy'de her gün her ögün yemek pişiren erkek yoktur. Yemek pişirmek kadının görevi haline gelmiştir. Ev içlerinde yakın geçmişe kadar mutfakta ocaklık yer almıştır. Ocaklıkta günlük olarak kadın tarafından yemek pişirilmiştir. Anadolu'da yakın zamana kadar yemek pişirmekte kilden yapılmış topların kullanıldığı bilinmektedir. Bilindiği kadarıyla Bozköy kadınları yemeklerde kil toplar kullanmamıştır. Yemek pişirilen ocaklık aynı zamanda kış mevsiminde oda içinde sıcaklık sağlayarak ısınma ihtiyacını gidermiştir. Farklı işlevsel özelliklere sahip ocaklığın potansiyel yangın sebebi olduğu ifade edilebilir. Ocağı yapan ve şekillendiren kadındır. Ocağın aile içi sosyal ilişkilerde önemi büyüktür. Günlük hayat mutfakta özellikle ocağın etrafında şekillenmiştir. Ocaklığın ateşini kadın hazırlamaktadır. Ocaklık, odun ve çalı çırpı ile yakılmaktadır. Mutfakta kadınların kullandığı çeşitli aletler bulunmaktadır. Nohut ögütmeye yarayan el değirmeni ve bulguru öğütmek için bulgur öğütme taşı ocaklığın hemen yanı başında bulunmaktadır. Yoğurt ve tereyağı gibi ikincil üretimler mutfakta kadınlar tarafından hazırlanmaktadır. Sağılan süt kadınlar tarafından büyük tencerelerde mayalanmaktadır. Elde edilen yoğurttan bez süzgüler yardımıyla tereyağı yapılmaktadır. Erkek özellikle mutfakta ihtiyaç duyulan bıçak bilemeyi elindeki biley taşı veya eğe ile yapmaktadır.

Mutfakta ocaklığın aksi istikametinde abdestlik olarak adlandırılan bulaşık yıkamak, yemek sonrası ağız ve el temizliği için ufak bir bölme bulunmaktadır. Ocaklığın hemen üst taraflarında kenar kısımlarda bardak, tabak vb. ihtiyaçları karşılamaya yönelik açık raflar (sergen) bulunmaktadır. Rafların dışında niş şeklinde bölmeler de bu ihtiyacı karşılamaya yönelik kadınlar tarafından düzenlenerek kullanılmaktadır. Mutfakta erkek sadece yemek yendiği zaman bulunurken yemek sonrası erkek mutfaktan çıkmaktadır. Kadın mutfaktaki varlığını devam ettirmektedir. Bulaşık yıkamak için abdestlik kullanılır. Kadına mutfakta diğer kadınlar veya kız çocukları yardım etmektedir. Yakın geçmişe dek içme suyu veya yemeklerde kullanılacak su genç kızlar tarafından 5 litrelik testilerle köyün yaklaşık 500 metre dışındaki pınardan karşılanmıştır. Erkekler ise yemek sonrası genelde zamanlarını kamusal alan olan kahvehanelerde geçirirler.

1955 ve öncesi yıllarda mutfaklar tek katlı düz dam şeklinde hayvan damlarına ve ahırlara uzak olmayacak şekilde tasarlanmışlardır. Düz dam oluşturmak için gereken ayçiçeği sapları, deniz yosunları, kil çamur ve diğer yapı malzemeleri kadın ve erkek arasındaki iş bölümü sayesinde taşınmış ve inşa edilmiştir. Erkekler damı inşa ederlerken, kadınlar duvarların sıvasını yaparlar. 
Kurban Bayramı'nda kurban edilen hayvanın etleri kadınlar tarafindan genelde mutfakta doğranmaktadır. Buzdolabı olmayan dönemlerde etler kadınlar tarafından mutfak içindeki ocaklarda kavrulmaktadır. Kavrulan etler kavanozlara veya çeşitli kaplara konularak daha sonra yenmek üzere kilere kaldırılmaktadır. Bugün modern mutfaklarla ihtiyaçlar daha az zahmetle, hijyenik ortamlarda zaman kazanarak yapılıyor olsa dahi kadın günlük işlerini mutfakta yapmayı sürdürmektedir.

Köye elektrik 1982 yılında gelmiştir. Su ihtiyacı ise ilk olarak kuyulardan sağlanırken 1950'li yıllarda Bozköy-Hanaytepe Höyüğü'nün bulunduğu kaynaktan yerden geçen bir su borusu hattı imece usulü kazılarak köye tek çeşmeden su sağlanmıştır. 1960'lı yıllarda Devlet Su İşleri (DSİ) tarafından köye üç adet çeşme yapılarak su sağlanmıştır. Ancak su hatlarında problem oluşur ve 1970'lerin sonunda çevre köylerin birleşmesi ile Pınarbaşı köyünden tüm konutlara ve bahçelere su verilmeye başlanır. Günümüzde içme suyu köydeki arıtma sisteminden karşılanırken, kullanım suyu Mahmudiye (Aktepe) köyünden sağlanmaktadır. Su 1970'lerin sonu itibari ile evin içine girmiştir. Daha öncesinde hamama (banyo) gerekli olan su kadınların omuzlarında su testileri ile evin içine getirilmiştir. Kadınlar testilerle su almaya gittiklerinde kendilerini kamusal alanda sosyal hayat içinde bulmuşlardır. Elektriğin olmadığ yıllarda ailenin tüm fertleri kadının getirdiği, 1sıttığg ve kaplara taksim ettiği su ile banyoda ihtiyacını karşılamıştır. Geçmişte hamam veya banyo tek kişinin girebildiği tahta kapısı olan çok ufak bir bölmedir. Köyde doğalgaz olmadığından çoğunlukla şofben ile elektrikli 1sıtıcılar vasıtasıyla, kadın tarafından oturma odasında kurulan sobada veya banyo içindeki tüplerde su 1sıtılmaktadır. Banyonun gerekli temizliği kadınlar tarafından yapılmaktadır. 1970'li yıllarda zeytincilik sayesinde zeytinyağından elde edilen sabunlar kişisel temizlik için önemli hale gelmiştir. Sabunların üretimini yapan, ev içinde istifleyen ve kimi durumda ekonomik kazanca dönüştüren kadındır. Bugün modern banyolarda bulunan çamaşır makineleri kadınlar tarafından kullanılmaktadır ve erkek banyoda kişisel temizliği dışında bulunmamaktadır.

Köydeki evlerin oturma odalarında kadınlar tarafından üretilen hasır yaygılar, danteller, örtüler, yastık, yorgan kılıfları, perdeler geçmişten günümüze değin kendini açıkça göstermektedir. El işleri sayesinde kadınlar mekânın içini süsleyip güzelleştirerek renklendirebilmektedirler ${ }^{76}$. Masalara, sehpalara, koltuklara serilen örtülerin el işçiliğini kadınlar yapmaktadır. Kadın zamanı doğrultusunda örgü örme ve ip eğirme gibi el işlerini de oturma odasında yapabilmektedir. Ailenin ihtiyaçları karşılanmakta veya örgüler odalarda süs eşyası olarak kullanılmaktadır. Perdeleri belirleyen, asan ve perdelerin temizliğini kadın yapmaktadır. Bozköy kadınlarının evlerinde görülen kilimler ve halılar çevre ilçeler Çan ve Bayramiç gibi köylerde hemcinslerinin işlemiş oldukları halı ve kilimlerdir. Oturma odasının

\footnotetext{
${ }^{76}$ Ertuğ, 2010: 88.
} 
tüm temizliğini ve düzenlemesini kadın yapmaktadır. Oturma odasına kurulan sobadan, sobanın yakılmasına, bahar aylarında sobanın kaldırılmasına ve baca temizliğine kadar kadın tüm soba işlerini yapmaktadır. Soba tıpkı mutfaklardaki ocaklık gibi kırsal kesim için potansiyel yangın nedenidir.

Kadın genellikle bahar aylarında evin tümünden ziyade özellikle evin ortak kullanım alanlarında badana veya boya yapmaktadır. Oturma odası da bu yerlerden birisidir. Evin iç beğenisi kadının kontrolü altındadır. Bazı evlerde köyün dışından kadınlar tarafından getirilen kırmızı kille tavana özel sıva yapılarak komşu evlerden farklı malzeme kullanılmaktadır. Geçmiş yıllarda kerpicin kullanıldığı dönemlerde kadınlar evlerini kerpiçle sıvamışlardır. Elektriğin köye gelmesi ile evin içine televizyon girmiştir. Elektriğin köye gelmeden ev içinde mutfakta şekillenen sosyal organizasyon yavaş yavaş oturma odasına doğru kaymıştır. Erkek evin diğer bölümlerinde olduğu gibi oturma odası içinde de etkin bir role sahip değildir. Pek çok Anadolu köyünde görülen erkek ve kadına ait haremlik selamlık bölümleri Bozköy’deki evlerde görülmemektedir. Kadın doğum ve özel günleri dışında oturma odasında bulunmaktadir.

Ev içinde önemli bir yere sahip olan oturma odasının geniş olması nedeniyle mevlit, anma veya kutlama törenleri düzenlenmektedir. Ev mevlitlerinde erkekler yoktur. Kadın okuyucular tarafından ve sadece kadınlara okunur. Her mevlidin mutlaka bir ikramı olur. Şimdilerde pilav, yoğurt ve tulumba tatlısı olan bu ikram, önceleri lokma, peynir ve reçel türü veya keşkek ile çorba-sulu yemek türü ikramı kapsamaktadır.

1970'li yıllarla birlikte artan nüfusla köye gelen misafir sayısına paralel misafir odası ihtiyacı doğmuştur. "gizlence odası" olarak adlandırılan bu mekânlar sadece misafirlere özel odalardır ve diğer odalarla bağlantılı değildir. Misafirler konuk oldukları evlerde hemen misafir odasına buyur edilir, her türlü iş bırakılır, misafirlerle ilgilenilir ve günlük işler konuşulur. Misafirlerin yatacakları yerleri belirleyen, onların temiz nevresimlerini, battaniye, yorgan gibi ihtiyaçlarını kadın temin etmektedir. Kadınlar en temiz halleriyle misafirlerinin karşısına çıkmak isterler. Düşünceli ve duygusal davranış özelliklerine sahip kadın gelen misafirlere mahcup olmak istemez. Kendisine ve aile reisi olan eşine karşı sorumluluk duygusu ile hareket eder. Misafire hürmette kusur edilmez. Köydeki bazı misafir odalarında kışın kurulan sobalar bulunmaktadır. Sobanın yakacağı kadın tarafından hazırlanır. Kadın odanın temizliğinden ve düzeninden sorumludur.

\section{Ev dışında toplumsal cinsiyet rolleri}

Yukarıda ev içi öğeler kapsamında kadın ve erkeğin toplumsal rolleri üzerinde durulmuştur. Ev dışı denildiğinde iç avlu (bahçe), dış avlu, kiler (ambar), sundurmalar, eski ahırlar, samanlıklar ve 
zeytincilikle beraber zeytin ve zeytinyağı depolama alanları gibi zeytine dair ev dışı öğeler bağlamında kadın ve erkeğin rolleri üzerinde durulmaya çalışılacaktır.

İç avluda pek çok türdeki iş kadın tarafından yapılırken erkek bahçedeki odunları keser. İç avluda sadece ailenin ihtiyacı kadar ıspanak, marul, domates, biber, patlıcan, nane, dereotu, maydanoz, soğan, sarımsak vb. ekilir. Kadın fidanları eker, çapa yapar, bitkileri sular, gerektiğinde bitkilere hayvan gübresi verir ve ürün olgunlaştığında toplar (Res. 5). Aile içi ekonomik değer olarak değerlendirilebilecek iç avlu faaliyetleri pek çok alanda olduğu gibi kadının emeği ile yürümektedir; iç avluda sonbahar zamanında salça yapılırken sebze ve meyve kurutması (kak) organize edilmektedir. Ayrıca tarhana, kuskus, yufka gibi hububat ağırlıklı besinler de yine sonbaharda kadınlar tarafından yapılır. Kadın aynı zamanda iç avluda süs bitkileri yetiştirir, 1sınmada kullanılan ve erkekler tarafından kesilen zeytin ağacından odunları iç avluda istiflemektedir. İç avluda bahar aylarının sonuna doğru sazlardan elde edilen ve evlerin özellikle oturma odalarına serilen hasır yaygılar kadınlar tarafından gölgede örülmektedir. Bu işlem dış avlu kısmında da yapılabilir. İç avlu her evde bulunmazken dış avluya nazaran daha az yer kaplamaktadır.

Kadın ve erkeğin farklı becerileri ile ortaya çıkan el işleri arasında iç ve dış avlunun yer temizliğinde kullanılan çalı süpürgeleri başta gelmektedir. Evlerin dış avlusunda yetiştirilen ve bitkilerin kurutulması ile elde edilen bu süpürgelerin yapımında ve kullanımında kadınlar etkin rol oynamaktadır. 1970'li yıllarda ev tabanlarına serilen hasır yaygılar bugün kullanılmamaktadır. Dokuma tezgâhlarının başında kadınlar bulunurken tezgâhlar dış avluda yer almıştır. Kadınlar ayrıca avlularda yer alan büyük fırınların ihtiyacı olan kürekleri ve süpürgeleri el işçilikleri sayesinde yapabilmişlerdir.

Yukarıda iç avluda organize edilen faaliyetler arasında bahsedilen salça, sebze ve meyve kurutması (kak) gibi kışa yönelik hazırlıklar dış avlu kısmında da gerçekleşebilmektedir. Aynı şekilde tarhana, kuskus, yufka gibi hububat ağırlıklı besinler de yine sonbaharda kadınlar tarafından kış için dış avluda yap1labilmektedir.

Dış avluda yeteri kadar alan olduğu takdirde düğünler yapılabilmektedir. Düğün organizasyonunda kadın önemli bir role sahiptir. Yemek pişirilir, misafirler ağırlanır ve ikramlarda bulunurken kadınlar birbirlerine yardımcı olmaktadırlar. Erkekler aynı zamanda keşkek için gerekli buğdayı dövmede yardımcı rol üstlenmektedirler.

Bozköy halkı Kurban Bayramı zamanında küçükbaş veya büyükbaş hayvan kurban ederler. Dış avluda gerçekleştirilen faaliyetlerde ilk önce hayvanın kesileceği yer belirlenir. Evin erkekleri kurbanlarının 
kesimini yapabildikleri gibi gerektiğinde köy imamı tarafından köydeki ihtiyaç sahiplerinin kurbanı başından kesilerek köylüye yardımcı olunmaktadır. Kurban edilen hayvanın yüzülmesi, organların çıkarılması ve etlerin büyük parçalara ayrılması erkekler tarafından organize edilmektedir. Kadınlar kurbanın sakatatlarını ve kurbandan arta kalan pisliği temizleyerek ev içinde etleri doğrama işlemine geçerler.

Artı değerin zeytinciliğe nazaran düşük olduğu 1960 öncesindeki hayvancılıkta rollerin cinsiyete göre dağıtıldı̆̆ı bir iş bölümü bulunmamaktadır. Herkesin her işi yapabildiği bir dönemdir. Hayvansal ürünlerden az da olsa ekonomik kazanç elde edilmektedir. Süt, yoğurt, peynir, tereyağı gibi ürünler ihtiyacı karşılamaya yönelik ev içinde tüketilmektedir. Elektriğin olmadığı ve buzdolabı kullanılmayan Kurban Bayramı zamanında kurban edilen hayvanın eti kadınlar tarafından mutfakta kavrulmaktadır. Kavrulan etler çeşitli kaplara konulup ilerleyen zamanlarda tüketilmek üzere ambara erkekler tarafından kaldırılmakta ve istiflenmektedir (Res. 7). Süt sağmak ilk başlarda kadın ve erkeğin iş bölümünde iken sonradan bu duruma kadınlar sahip çıkmıştır. Dış avluda kurulmuş genelde mutfakların yakınındaki ahırlarda sütü sağan kadın olurken, hayvanlar kadın ve erkeğin ortak iş bölümü neticesinde beslenmektedir. Hayvanların bulunduğu ahırların temizliğinde kadın ve erkek arasında belirgin bir iş bölümü anlayışı yoktur. Kim müsaitse ahırlardaki hayvan pisliğini temizler, bahçede kullanılacak gübre için de dış avluda bir köşeye hayvan pisliğini biriktirir. Zamanı geldiğinde toprağa karıştırılmak üzere kadın veya erkeğin kontrolünde gübre olduğu yerden alınır. Erkekler ağır olan saman balyalarını dış avluda genelde ahırların hemen yanında kurulmuş olan samanlıktan çıkarırlar (Res. 8).

Özellikle hayvancılık ekonomisine dayalı dönemde köyde evler sıklıkla kerpiçten yapılmıştır (Res. 9). Kadınlar ve erkekler evlerinin ihtiyaç duyduğu kerpiç tuğlaları saman ve killi toprağı karıştırarak dış avluda birlikte üretmektedirler. Birlikte üretilen kerpiç tuğlalar kurutulmak üzere diş avluya serilir. Köy halkı genelde taş temel üzerine kerpiç tuğlalar ve düz dam şeklinde mekânları inşa ederek dış avludaki yapı öğelerini oluşturmuştur. Yapının temiz ve sağlam kalmasına yönelik kadınlar iki yılda bir yapıları kerpiç ile sıvamaktadır.

Hayvancılığın ekonomik kazanç sağladığı yıllarda yük hayvanlarının kullanıldığı ve erkekler tarafından kullanılan hayvan arabaları ihtiyaç duyulmadığı vakitlerde dış avluda bekletilmiştir. Erkekler gün içinde hayvanların otlatılmasında karşımıza çıkmaktadır. Zeytinin köye gelmesi ile köy topraklarının kullanım şekli değişmiştir. Hayvan otlak alanları yerini zeytin ağaçlarına bırakmıştır. Zeytinin ekonomik kazancı ile köy zenginleşmiştir. 
Zeytincilik ile önceden hayvanlar için inşa edilmiş yapılarda değişikliklere gidilmiştir. Hayvancılık için kullanılan dış avluda zeytin ve zeytinyağının depolandığı alanlar yaratılmıştır (Res. 10-11). Hasat döneminde tarladan gelen zeytinler dış avluda ve zeytin için oluşturulan yeni yapılarda kadın ve erkeğin iş bölümünde işlemden geçmektedir. Traktör kullanan kadın nadirdir. Erkek traktörle tarladan getirmiş olduğu zeytin kasalarını işleme alınacak dış avluya indirmektedir. Fiziksel güç isteyen bu iş, bereketli hasat dönemlerinde yüzlerce hatta binlerce kasanın indirilip kaldırılmasıyla erkeğin yapabildiği bir iştir. Kasalardaki zeytin, yağlık, salamura ve çizik olmak üzere ayrılacağı dış avludaki masanın başına getirilmektedir. Masa başında genelde üç kadın bulunmaktadır. Ayrım masada kadınlar tarafından kabaca gerçekleştirilmektedir (Res. 12). Erkek nadiren masa başında çalışmaktadır. Erkekler dış avluda zaman açısından karlı olan zeytin makinelerinin bulunduğu yapıda zeytinlerin boyunu ayıran makineyi çalıştırmaktadır (Res. 13). Makinedeki ayrım nihai ayrımdır. Zeytini çizik hale getiren makineler bulunmaktadır. Boylarına göre ayrılan ve çizilen zeytinler fabrikaya erkekler tarafından götürülmektedir.

Kadınlar bugün halâ zeytinyağından sabun üretmektedirler. Sabunun tüm üretim aşamalarında kadın rol almaktadır. Erkek sadece ahşap sabun kalıplarının oluşturulmasında rol almaktadır. Üretilen sabunlar ekonomik kazanç sağlamaktadır. Bu faaliyet daha çok dış avluda yapılmaktadır.

Dış avluda özellikle mimari öğelerin inşaatında erkekler önemli rol üstlenmektedir. Hayvancılık döneminde düz dam olan yapılar zeytinciliğin ekonomiye girmesi ile çatılarda kiremit kullanılmıştır. Sosyo-ekonomik değişikliklerin mimariye yansımasında iş gücü rolü açısından erkek ön plandadır. Temel kazısında, duvar örmede, çatı yapmada veya çatı aktarmada erkekler görev alırken kadınlar mimari anlayışın belirleyicisi olmuşlardır. Özellikle dış avluda yapı öğelerinin inşasında, kiler, samanlık gibi depolama alanlarında fiziksel güç isteyen alanlarda erkek etkin rol oynamaktadır (Pl. 1). Kadınlar ise inşaat malzemesinin taşınmasında yardımcı rol alırlar.

Fırınlar hane halkı için büyük öneme sahip mimari öğeler arasında yer almaktadır. Dış avluda bulunan fırınlar geçmişten günümüze kullanılmış ve kullanılmaya devam edilmektedir. Kadınlar avlularda yer alan büyük firınlardan ev içindeki maltız yapımına dek yemek pişirme fonksiyonuna sahip tüm öğelerin yapımında ana rolleri üstlenmektedirler (Res. 14). Kadınlar sadece aile içindeki 8-10 kişilik yemekleri hazırlayıp sunmakla kalmaz düğün, mevlit, cenaze gibi törenlerde kalabalık insan gruplarına da yemek hazırlar ve sunarlar. Büyük tören kapları (Res. 15) içinde tüm köye yetecek kadar yemeği dış avluda kurulan ocak üstünde kadınlar hazırlamakta ve dağıtımını erkeklerin yardımıyla avluda gerçekleştirmektedirler. Evin dışında avluda büyük firınlar köyün her hanesinde bulunmaktadır. 
Fırınlarda mekân içindeki ocaklarda yapılan yemekler yapılmamaktadır. Fırınlarda piniyet ${ }^{77}$ (Res. 16) içinde ekmek, börek ve et pişirilmektedir. Fırınların kurulmasında ve yemek yapımında kadınlar ana rol oynamaktadır (Res. 17). Kadının emeği ile yaratılan fırınlar kadının büyük organizasyonları yapabilmekteki becerisini ve bu bağlamda toplumsal rolü hakkında fikir verebilmektedir. Köy halkı özellikle 1970'li yıllar ve öncesinde ihtiyaç duyduğu unu, köyün ortak malı haline gelmiş tek dibek taşından erkeklerin unu dövmesi ile gidermektedir. Erkekler unu döver, çuvallara koyup mekâna kadar taşır ve sonra kadın devreye girer. Dövülmüş undan ekmek yapmak kadının görevi haline gelmiştir.

Sundurma veya veranda olarak ele alınan mekân, evle iç içe geçmiş eve girişte veya evden çıkıştaki ilk adımdır. Sundurma, bir kapı herhangi bir geçidin dış girişine çatı olacak biçimde, girişi yağmurdan güneşten korumak amacıyla arkası duvara yaslanan yapı çeşididir. Yerel mimariye göre değişkenlik gösterebilecek pek çok sundurma tipi bulunmaktadır. Yapıların dış cephelerinde bulunan sundurmalar yerle temassız olabileceği gibi parmaklık veya ince duvarlarla desteklenebilir. Sundurmaların altındaki zemin yer ile aynı hizada olabilir veya birkaç basamaklık merdiven ile çıkılabilir. En az bir kişinin rahatlıkla içinde durabileceği boyutlarda inşa edilir. Sundurmaların daha büyük boyutlarda bütün ön cepheyi kaplayan türlerine veranda denir. Bozköy'de evlerin ekonomik durumuna göre dar veya geniş ölçekte veranda boyutunda sundurmalara rastlanmaktadır (Res. 18-19). Geniş sundurmaların altında havaların güzel olduğu zamanlarda kadınların hazırladığı ve tüm hane halkının sofraya oturduğu yemekler yenmektedir.

Sundurmanın altında evin içinde kullanılamayacak derecede eskimiş, ancak sundurmada kullanılabilecek mobilyalar bulunabilmektedir. Mobilyaların dışarıya çıkarılmasına kadınlar karar verirken erkekler mobilyaların çıkarılmasına yardımcı olmaktadır. Sundurmanın altında ayakkabılık, çeşit çeşit saksılar ve zeytinle ilgili kaplar bulunmaktadır. Kapların nereye konacağından, boyanacak ayakkabılığa, saksılardaki çiçeklerin bakımına kadar tüm işleri kadın üstlenmiş vaziyettedir. Sundurmanın altında eğer yer varsa çeşit çeşit sebze ve meyveler kış için kurutulur. Tarhana, yufka gibi gıdalar kış için hazırlanırken, konservelerin bir bölümü sundurmanın altında hazırlanmaktadır. Ayrıca sundurmanın altında çocuklara rahatlıkla göz kulak olunmakta ve sokakla doğrudan bağlantısı olmadığı için kadınlara rahat hareket alanı sağlamaktadır.

\section{KAMUSAL ALANDA TOPLUMSAL CINSIYYET ROLLERI}

Her insanın dünyasını öncelikle doğduğu ev, aile ve mevcut yerleşim yeri belirler. Aile ve yerleşimin gelenekleri, inançları, sosyo-ekonomik durumu mekânların belirleyicisidir. Bozköy’deki gözlemler ve

\footnotetext{
${ }^{77}$ Piniyet, ekmek yapımında kullanılan ahşap kaptır; bir nevi ekmek teknesidir. Ekmek hamuru dörtlü veya sekizli bölmeler halinde hazırlanmış yerlere konarak firına sürülmektedir.
} 
sözlü mülakatlar neticesinde sınırların cinsiyetlere göre belirlendiği anlaşılmıştır. Erkekler için sınırlar daha esnek olabilmektedir. Okula özellikle üniversite eğitimi için şehir dışına gitmek erkek çocuklar için daha mümkündür. Askere veya tek başına şehre gitmek gibi mekânın sınırlarını esnetmek erkeklere doğuştan tanınan haklardandır. Bozköy'de askerler dua ile uğurlanır. Evinden köyün çıkışına kadar duayla bütün köy halkı askere eşlik eder ve asker herkesin elini öperek helallik almaktadır. Gelenek olduğundan askere harçlık verilmektedir. Askerlik, köye gelen yabancılarla iletişim kurmak, köy dışında çalışmak ve eğitim için gidilen yerlerdeki yabancılarla iletişime geçmek erkekler için deneyim anlamına gelirken, kadınlara evleri ve köyleriyle sınırlı bir mekân geride kalmıştır. Kadınlar köylerindeki kamusal alanlardan yararlanamazlar. Bozköy kadını için ev ne kadar kendine aitse kamusal alan o kadar yabancidır.

Şebeke suyunun henüz olmadığı ekonominin hayvancılığa bağlı olduğu 1955 öncesinde mutfağa gereken günlük su ihtiyacı 15 - 20 litre kapasiteli testilerle kadınlar tarafından 1950’li yıllarda köy meydanındaki çeşmeden taşınmıştır (Res. 20-21). Bu sayede eve bağlı hayat yaşayan kadın dışarıya çıkarak sosyalleşme şansı elde etmiştir ${ }^{78}$. Evin bahçesi yeterli olmadığı durumlarda düğünler köy meydanında gerçekleşir. Düğünlerde kadınlar yemek pişirirken erkekler yemeklerin dağıtılmasında kadınlara yardımcı olmaktadırlar.

Bozköy ve çevresindeki köylerde her yıl hasadın iyi geçmesi temennisi ile "hayırlar" düzenlenmektedir. Her köy kendi hayrını köy meydanında düzenler ve masrafları karşılar. Bozköy'de düzenlenecek olan hayra köy ahalisi her türlü desteğini sunarken çevre köylerin insanları davet edilmektedir. Hayırlarda yemekler yapılır, yenilir, içilir ve bahar aylarından itibaren doğanın bereketli olması temennisinde bulunulur. Hayırlarda kadınlar çok fazla rol üstlenir. Yemeklerin yapılmasından sunumuna kadar kadın önemli rol oynamaktadır. Bu bağlamda Çanakkale genelindeki köy hayırlarına dair yapılan yüksek lisans tezinden bahsetmek gerekmektedir ${ }^{79}$. Araştırma kapsamında seçilen örnek köy hayırları Çanakkale ilinin birçok kırsal yerleşmesinde düzenlenmektedir. Araştırmada köy hayırlarının dağılış özelliklerinin coğrafi ortamla ilişkisi değerlendirilmiştir. İl ölçeğinde dağılış gösteren çeşitli büyüklükteki köy hayırlarının, köylerin temel geçim kaynakları, sosyo-kültürel özellikleri, il ve ilçe merkezi ile var olan ulaşım bağlantıları açısından analiz edilmiştir. Coğrafi değerlendirmelerin yanı sıra köy hayırlarında kadın ve erkeğin üstlendikleri rollere dair bilgiler verilmiştir.

\footnotetext{
${ }^{78}$ Edgü, 2010: 79.

${ }^{79}$ Çavuşoğlu, 2015.
} 
Sokakların kullanımı herkese açıktır ve sokakları en fazla çocuklar kullanmaktadır. Çocuklar hıdrellez zamanında köyün tüm sokaklarını gezerek her evin kapısını çalar. Hane halkından çeşitli hediyeler çocuklara verilerek çocuklar mutlu edilir. Sokaklar hane halkını köyün geri kalan kısmından ayıran kamusal alanlardır. Sokaklar evin dış avludaki yüksek duvarlarla mahremiyet göz önüne alınarak ayrılmıştır. Kültürümüzde erkeklere atfedilen evin direği ifadesi kadının farkında olarak veya olmadan erkeğin kadın üzerinde kurmaya çalıştığı egemenlik isteğidir ${ }^{80}$.

Köy meydanı çocukların aynı zamanda oyun alanları arasında yer almaktadır (Res. 22). Çocukların sünnet mevlitleri de köy meydanında okutulmuş ve okutulmaya devam edilmektedir. Cami ve meydanda okutulan mevlitlerde erkekler mevlit okuyan, imam veya mevlit dinleyicileri bağlamında kamusal alanın belirleyicisi konumundadır. Mevlit sırasında kadınlar mevlidi dinlemeye çekilir.

Nüfusun kalabalık olduğu 1970'li yıllarda baharın habercisi hıdrellez şenlikleri köy meydanında düzenlenmiştir. Köy meydanında ateşler yakılır ve ateşin üzerinden atlanır. Hıdrellez akşamı köyün tüm genç kız ve erkekleri köy meydanındaki kahvenin önünde toplanıp maniler söyleyerek önemli bir sosyo-kültürel aktivite gerçekleştirirler.

Köy meydanında önemli kamu yapıları arasında muhtarlık ve kahvehaneler bulunmaktadır (Res. 23). Geçmişten günümüze kahvehaneler veya kahveler genelde meydanın çevresinde kurulmuştur. Günümüzde sadece bir tane kahvehane vardır ve aile tarafından işletilmektedir. Mekânın sahibi erkek olmadığı zaman, mekân ailedeki eş olan kadın tarafından işletilmektedir. Kahveler kamusal alanlardır; ancak geçmişte erkeklerin tek başlarına veya hemcinsleri ile var oldukları yerler olmuştur. Kahvelerde genelde erkekler çalışırken, sadece erkekler kahveye girebilmiştir. Kahvelerin önünden kadınların geçmesi ayıp karşılanmıştır. Kahvelerde yaşlı erkekler akranları ile vakit geçirirken 1970'li yıllarda kahvelerde genç erkeklerin "gençlik odası" denilen kahvenin içinde tek odalı mekânda yaşıtları ile vakit geçirdikleri bilinmektedir. Kahveler zamanla siyasetin seçmenle buluştuğu yer haline gelmiştir. Seçim dönemlerinde seçmenle buluşmak isteyen siyasiler kahveleri tercih eder olmuşlardır. Siyaset kahvelerde sadece erkeklerle bir araya gelirken kadınların fikri alınmamıştır.

Kadınlar cenaze, cuma, bayram ve vakit namazlarına gidemezlerken Ramazan ayı içindeki teravih namazlarına gidebilmektedirler. Erkekler cami içinde istedikleri vakit namazlarını kılabilirler, avlusunda abdest alabilirler, sohbet edebilirler; ancak kadınlar camiye sadece Ramazan ayı içinde girebilmektedirler. Camiye gelen cemaatin başında bir din görevlisi bulunmaktadır. Cami içindeki din görevlileri erkektir. Cemaate dini bayramlarda, cenazelerde ve cuma günlerinde namazı imam

${ }^{80}$ Edgü, 2010: 77. 
kıldırmaktadır. Bayram günlerinde özellikle cami avlusunda erkeklerin birbirleriyle bayramlaştıkları görülmektedir. Yaşlı veya çocuk fark etmeksizin köyün tüm erkekleri bir araya gelmektedir. İmam günümüzde eğitime açık olmayan bir başka kamusal yapı olan okulun lojmanında ikamet etmektedir. Camide sadece namaz kılınmaz, mevlit okunabilmektedir. Mevlit okunduğu sırada hayırlar dağıtılmaktadır. Namazda olduğu gibi yine burada kadınlar bulunmamaktadır. Mevlit erkek tarafından okunurken, onu cami içinde veya avluda dinleyen başka erkeklerdir. Kadınlar erkeklerden ayrı yerde mevlit dinlerler. Camiler dini inançlarını yerine getirildiği ruhani ve aynı zamanda insanların birbirleriyle sosyalleştikleri mekânlardır.

Cami avlusunda köy odası bulunmaktadır. Köy odası 1960'lı ve 1970'li y1llarda uzaklardan gelen misafirlere ayrılmış bir mekândır. Zamanla Ramazan ayı akşamları iftar sofralarının kurulduğu ve cemaatle yemeklerin yenildiği bir odaya dönüşmüştür. Bugün ilk kullanım amacını yitirmiş halde muhtarlığın deposu olarak kullanılmaktadır.

Muhtarlık kurumunun varlığından itibaren Bozköy tarihinde muhtarlık görevinde bulunmuş veya ihtiyar heyeti içinde yer almış tek bir kadın yoktur. Kadınların siyasal topluluğa tam üye olamamalarının nedeni kamusal / özel mekân ayrımından kaynaklanan ayrıştırmanın kendilerini ekonomik yaşamdan uzak tutmasıdır. Siyasetin temel belirleyicisi kamusal alan olunca özel alanın (mekânın) mahrem konuları ve burada yaşayanların sorunları gündemden ve gözden uzak tutulmuş, kadının iktidar ilişkilerinin sorgulanmasının önü kapatılmıştır. Kadınlar uzun yıllar medeni ve siyasal haklardan mahrum edilmiş, bu tür hakların sadece burjuva erkeklerine ait olduğu düşünülmüştür ${ }^{81}$.

Bozköy’de kadın evinin kadınıdır ve tüm köye idareci olarak hizmet etmesi doğru karşılanmamaktadır. Kadın biyolojik doğurganlığı sebebiyle gerek çocuk gerekse köy işlerinin üstesinden aynı anda ve oranda gelebileceğine dair yaygın inancın olmaması erkek bakış açısı ile değerlendirilmektedir. Tüm köyün idari işlerinden sorumlu olan kişinin erkek olduğu düşünüldüğünde, erkek bakış açııı köyün idari işlerine hakim konumdadır. Muhtarlar son zamanlara kadar köyde ailesi ile yaşamıştır.

Yukarıda üzerinde durulan kamusal alanlarda kadının ayrı tutulduğu gerçeği köy dışındaki kamusal alanlarda da karşımıza çıkmaktadır. Halbuki fikir üret kadın, erkekten daha becerikli iken sadece mahremiyet nedeniyle kamusal alanlarda ve dolayısıyla köyün dışında doğal yerini alamamıştır. Ancak yine de kadın hiç yoktur denilemez. Ekonominin hayvancılığa dayalı olduğu zamanlarda hayvan ürününden elde edilen çorap, eldiven, yastık, yorgan yününü kadınlar evlerinde işlemektedir. Erkekler ise o dönem terzilik zanaatı ile karşımıza çıkmaktadır. Erkekler özellikle pantolon ve ceket gibi giysiler

${ }^{81}$ Çakır, 2010: 141. 
üreterek ev ekonomilerine katkıda bulunmuşlardır. İşlenen bu ürünler yılda bir kez birkaç günlüğüne 1960’lı yıllardan beri kurulan Geleneksel Ezine Panayırı'nda satılmıştır.

Erkekler mevsimine uygun olarak tavşan, kuş, sığırcık avına katılırlar. Kimi zaman erkekler grup halinde Kaz Dağı'na avcılık yapmaya giderler. Avcılık herhangi bir ekonomik değer taşımamakta, tamamen erkeklerin merakına ve sosyal yaşantısına bağlıdır. Köyde ava çıkan kadın yoktur. Kamusal alanın egemeni olan erkek, ava çıkıp avladıkları hayvanları eve getirmektedir. Kadın erkeğin avladığı hayvanların mutfakta pişirilmesinden ve sunulmasından sorumludur.

\section{TARIM ARAZILERINDE TOPLUMSAL CINSIYYET ROLLERİ}

Bozköy insanları için zeytincilik tarım arazilerinde çalışarak paylaşımın, dayanışmanın, fikir ve bilgi alışverişlerinin gerçekleştiği, her türlü hava koşullarında aileler için ekonomik kazancın temel alındığı faaliyettir. Bozköy'de mevcut zeytin ağaçlarının arasında yeni dikilmiş fidanlar da göze çarpmaktadır. 1960'lı yıllarda ilk zeytin fidanları yabani halde yaklaşık 10 km mesafedeki Fığlı Dağı'ndan erkekler tarafından getirilip aşısı yapılarak dikilmiştir. Bu süreç uzun, zorlu ve sabır isteyen bir süreçtir. 1970'li yıllarla beraber dikilen fidanlardan ürün alınmaya başlanmıştır. Ekim, kasım, aralık aylarını içine alan hasat zamanı geldiğinde kadın ve erkeğin rolleri daha da belirgin şekilde ortaya çıkmaktadır. Tarlada kadınlar ve erkekler birlikte çalışmaktadır. Öncelikle ağaç diplerine önceden düşmüş olan zeytinleri kadınlar toplayarak önceleri "kelatir" denilen "küfeye", hasır ve ayıttan ${ }^{82}$ sepetlere veya köy dışından satın alınan sanayi tipi bez çuvallara, bugün ise plastik kasalar içine koymaktadırlar (Res. 24-26). Ağaç diplerine kadınlar "yaygı" denilen geniş bir bez veya naylon sermektedirler. Yaygının işlevi ağaçtan düşen zeytinleri direkt olarak toprakla temas etmesini engelleyerek zeytinlerin bozulmadan temiz kalmalarını sağlamaktır. Erkekler ellerine aldıkları sırıklarla ağacın tepesindeki zeytinleri dallarından ayırmaktadır. Kadınlar ise boy hizalarındaki zeytinleri "tarak" denilen aletle (Res. 27) ellerindeki küçük sepetlere (Res. 28) veya yaygı üzerine toplamaktadırlar. Kasalara toplanan zeytinleri traktörlere yükleme görevini ve zeytinin eve sevkiyatını erkekler gerçekleştirmektedir (Res. 29). Bozköy'deki gözlemler ve sözlü mülakatlar neticesinde genelde bir zeytin ağacının başında iki kadının çalıştığ 1 anlaşılmıştır. Erkek işçi sayısı kadınlara nazaran daha azdır ve erkekler sırık yardımı ile bir ağaçtan diğerine sürekli hareket halinde çalışırlar (Res. 30). Bir günlük iş için 14 kadın 3 erkek olduğunu varsayarak, bol ürün veren 2012 yılı hasat zamanında üç dönüm arazide çalışıldığı ifade edilmiştir. Ancak, az ürün veren 2013 yılı hasat zamanında ise yukarıda bahsedilen işçi sayısı ile bir günde yaklaşık 15 dönüm arazide çalışılmıştır. Bozköy'ün yerel insanı dışında işçiler genellikle Ayvacık, Çan

\footnotetext{
${ }^{82}$ Mine çiçeğigillerden, Akdeniz çevresinde yetişen, mavi, beyaz veya menekşe renginde çiçekler açan, 1-2 metre boyunda bir ağaççık, hayıt. (https://sozluk.gov.tr/?kelime=ay\%C4\%B1t; erişim tarihi: 26.08.2020).
} 
ve Bayramiç köylerinden gelmektedir. Çalışanlar sabahın erken saatlerinde yola çıkarlar ve sabah 7:00 ile akşam 16:00 saatleri arasında evlerinden 2 saatlik uzaklıkta çalışmaktadırlar. Yakın yerlerin dışında Keşan gibi uzak yerlerden zeytin hasadında çalışmaya gelen aileler de vardır. Aileler hizmet ettikleri kişilerin yanlarında üç ay yatılı kalmaktadırlar.

Tarım arazisinde ev içinde 1sınmaya yönelik zeytin ağaçları budanmaktadır. Erkek testere ile dalları keser ve budama yapar, yere düşen dalları toplamak fazlasını yakmak bazılarını evdeki fırın için ayırmak kadının görevidir. Traktöre yüklemek ve evde istifleyerek depolamak ise erkeğin görevleri arasındadır. Bu dalları alıp firında yakacak olarak kullanmak ise kadının sorumluluğundadır. Zeytin ağacının tüm kısımları değerlendirilmektedir. Yaprakları da gübre olarak zeytin ağaçlarının dibine serilmektedir. Tarım arazilerindeki bir başka faaliyet ise ot toplamaktır. Ot yemek için toplanır. Ege kültüründe yabani otların toplanıp yemeğinin pişirildiği görülmektedir. İlkbaharda kuzugöbeği ve sonbaharda "melki”" mantarı yaygın olarak toplanır. Bunların toplanması erkekler tarafindan yapılırken pişirmesini kadınlar yapar. Bunun yanı sıra kadınlar tarafından bazı otlardan ilaçlar yapılır; yara merhemi, karın ağrısı için içilen şurup en bilinenleridir. Günümüzde azalan nüfus beraberinde bazı geleneklerin unutulmasına yol açmaktadır.

\section{DEĞERLENDİRME VE SONUÇ}

Çalışmada üzerine basarak vurgulandığı üzere mekân veya ev içinde cinsiyete dayalı iş bölümü yerine kadının pek çok işi üstlendiği bir anlayış geçmişten günümüze dek Bozköy’de devam etmektedir. Çocukların bakımı, ev temizliği, yemeğin hazırlanıp sofraya konması, giysilerin dikilmesi, kışlık yiyeceklerin hazırlanması ve saklanması, kadınların bilgisinde, becerisinde ve sorumluluğunda gerçekleşmektedir. Bu yaşamsal ve mekânsal bilgiler sadece bir cinse özel, saklı gizli değildir. Ancak bunları her gün tekrarlayan, uygulayan ve hayata geçiren kadınlar olduğu için onlara özgü yerler ve yaşam biçimleri haline gelmiştir ${ }^{83}$. Biyolojik doğurganlık düşünüldüğünde anne olmak isteyen her kadın, üreten, besleyen, eğiten, geliştiren, koruyan konumunda olmaya devam edecek gibi görünmektedir. Ev içi kullanımda tüm el işlerini kadın yaparken, teknolojinin ve seri üretim yapan atölyelerin sonucunda bazı işler erkek işi olarak sayılmıştır. Örneğin terzilik zanaatı gibi. Ancak azalan nüfus, kitle iletişim araçlarının yaygınlaşması, eğitim ve kültür seviyesindeki artışlar kadının emeğine dayalı yaşam biçimini değiştirmektedir. Azalabilecek kadın nüfusu karşısında tek başına kalabilecek olan erkek, mekân içinin tüm rollerini üstlenmiş kadının rollerini üstlenmemesi durumunda yaşam biçiminde radikal değişikliklere uğrayabilir.

${ }^{83}$ Ertuğ, 2010: 86. 
Kadının yaşadığı coğrafya zaman içinde değişse bile yaşadığg evin iç mekânı kadının tercihlerine bağlı kalarak ayrıcalıklarla varlığını sürdürür. Mutfakta, oturma odasında, misafir odasında kısaca her yerde kadına ait ya bir el örgüsü, canlı bir çiçek, ateşi yanan soba, boyanmış duvarlar veya kadınlara ait erkeklerin aidiyet hissetmedikleri semboller vardır. Kadınlar bireysel kimliklerini ortaya koyabilecekleri düşüncesiyle erkeklerse sorumluluk duygusunun ağırlığı altında ailelerine ait bir yer sağlamak amacıyla ev sahibi olmak isterler ${ }^{84}$. Erkekler evleriyle faydaya dönük ilişki kurarken, kadınlar kendi açılarından anlamlı, içsel ve duygusal bir ilişki içindedirler. Kadının mekânla bütünleştiği bir başka ifadeyle mekâna bakarak kadının yansımasını görebilmek mümkündür ${ }^{85}$. Kadın mekânı istediği gibi düzenler, toparlar, dağıtır, değiştirir hatta yıkıp yeniden yapabilme gücüne sahiptir. Kadın ve mekân ilişkisi erkeğin mekânla kurduğu ilişkiden çok farklıdır. Kadın mekânına uzak değildir, mekânla iç içedir; samimi, yakın ve içinden geldiği gibi davranır. Erkek ise mekâna mesafeli bakar, ciddiyetle yaklaşır ${ }^{86}$.

Erkekler ve çocuklar sadece kadının yarattığı mekâna şahitlik ederler ${ }^{87}$. Belirgin şekilde erkek tüketirken kadın üretmektedir. Ancak aile içinde hiyerarşi söz konusudur ve en tepedeki erkektir. Erkek, çocuk eğitiminde ceza veya ödül kavramı ile ev içinde karşımıza çıkmaktadır. Genelde kız çocukları annelerini, erkek çocuklar ise babalarını rol modeli alırlar. Kuşaktan kuşağa aktarım söz konusudur. Ancak bugünün genç kuşağı, anne ve babalarından gerek modern hayatın her türlü olanağı yaratmış olmasından, köyde yaşanmıyor olmasından ve gerekliliğinin sorgulanması nedeniyle aktarımdan neredeyse faydalanmamaktadır. Bilgi aktarımının zayıflaması durumunda, sosyal belleğin azalması, kültürel kırılmaların yaşanması mümkün hale gelmektedir. Bu durumun bireysel kimlik üzerinde sorgulayan, taklit etmekten ziyade üreten veya farklı bakış açıları gösterebilen kişilerin gelişimine katkıları olabileceği gibi, köy hayırlarının, hıdrellez şenliklerinin, yemek çeşidinin, zeytinciliğin, renk ve cümbüşün giderek azalabileceği anlamına da gelmesi mümkündür ${ }^{88}$.

Azalan nüfusun iş bölümü, iş paylaşımı ve roller üzerinde etkisi vardır. Erkek nüfusunun azalması ile kadınlar neredeyse tüm işleri tek başına yapmak zorunda kalabilirler. Bu işlere fiziksel güç isteyen ağır yükler de dahildir. Kadının ortalama ömrünün erkekten fazla olduğu düşünülürse varsayım gibi gözüken durumların gerçeklik kazanması uzak bir ihtimal değildir. Kadının erkekten kalan rolleri üstlenmemesi durumunda ise uzun yıllardır süregelen alışkanlıkların ortadan kalkması mümkün hale gelmektedir. Tarım yerine emekliliğin yaşanacağı dolayısıyla mekân dışı yapı öğelerin kullanılmaması

\footnotetext{
${ }^{84}$ Hummon, 1984: 19

${ }^{85}$ Edgü, 2010: 74.

${ }^{86}$ Gezer, 2010: 103

${ }^{87}$ Gezer, 2010: 95.

${ }^{88}$ Ertuğ, 2010: 89.
} 
ve yapıların atıl hale gelmesi olasılık dahilindedir. Tüm bunların dışında kadının olmadığı yerde erkeğin tek başına kaldığı durumlar da söz konusu olabilir. Değişen koşullara göre oluşan davranış biçimleri geri kalan hayatın sosyo-ekonomik, kültürel, sosyolojik ve psikolojik boyutuna yansıması olabilir. Bir başka ifadeyle aile bireylerinden birisinin köyden ayrılıp göç etmesi, eğitim için başka şehirlerde bulunması veya vefat etmesi geri kalanlar için çok boyutlu anlamları beraberinde getirmektedir.

Mekân içinde belirgin, mekân dışında ise kadının kısmen olarak karşımıza çıktığı görülmüştür. Günlük hayatın şekillenmesinde pek çok rolü kadın üstlenirken, erkek daha az rol üstlenmiştir. Ancak kamusal alanlarda belirgin bir erkek egemenliği söz konusudur. Erkek her türlü kamusal alanda baskındır. Kadına kamusal alanda sadece köy meydanlarındaki çeşmelerde, Ramazan ayındaki teravih namazlarında, herkesin gelip geçtiği sokaklarda, hıdrellez zamanında kahve önlerinde, 2000'li yılların başına kadar eğitim veren okullarda rastlanmaktadır. Kadın kamusal alanlarda kısıtlanmış halde görülmektedir. Kahvehane gibi bir kamusal alanın tamamen erkeklere yönelik olduğu düşünüldüğünde, kadınların bu türlü yerlere sahip olamadığı, kahvehanelerin önünden geçmesinin ayıplandığı doğal sınırların görülmediği bir mekândan bahsedilmektedir.

Toplumsal cinsiyet rolleri kendiliğinden oluşmaz; kültürel süreçlerle, aile, okul, medya, siyasal veya üretim ilişkileriyle sonradan edinilir. Cinsiyet rollerine dayanan iş bölümü, tarihsel süreçlerle farklı otoritelerle denetim ve güç ilişkileri ağında yaratılır; toplumsal cinsiyet ilişkilerinde eşitliği veya eşitsizliği belirler. Özel ve kamusal mekân anlayışı, cinsiyetçi uygulamaların karşıtlık ve hiyerarşi oluşturacak şekilde bölünmüş ve örgütlenmiştir. Kadın fedakârlık, özveri ve duygusallık üzerine kurulu bir anlayışla değerlendirilir, doğayla özdeş tutulur ve akılcı özelliğine vurgu yapılmamaktadır. Erkek ise akılcıdır. Kamusal alanlarda yaşar ve yurttaş olarak kamusal alanın tüm haklarına sahiptir ${ }^{89}$. Bozköy’de kadın ve erkeğin arasında yazılı olmayan belirgin bir iş bölümü vardır. Kadın ve erkeğin kendi aralarında belirledikleri bu iş bölümü bir önceki neslin günümüze uyarlanarak sürdürülmeye devam ettiğini ifade etmek mümkündür. Bozköy'de kadın anne, eş, büyük anne, teyze, hala, abla, kardeş, işçi, emekli, ev hanımı, evli, dul şeklinde karşımıza çıkabilmektedir. Erkek de baba, eş, büyük baba, dayı, amca, ağabey, kardeş, evli, dul, işçi, işveren, emekli şeklinde varlığını sürdürmektedir. Aile reisi erkektir. Ancak pek çok ev içi ve ev dışı günlük iş ve sosyal organizasyon kadının etkin rolleri ile belirlenmektedir. Yukarıda bahsedilen törenler, ev içi yemek hazırlığı ve tüketiminde büyük rol oynayan kadın, aile içi ekonomik kazançlarda kısmen rol oynamaktadır. Bozköy kadınları yaşadıkları

${ }^{89}$ Çakır, 2010: 137. 
mekânların sosyo-ekonomik belleğidir. Onların yüzlerini ve bedenlerini bulduğumuz mekânlarda var kılmak, mekânları sadece yaşanan ev olarak değil, yaşamın sürdürüldüğü çevre ve ilişkiler ağı olarak da değerlendirmek önemlidir ${ }^{90}$. Toplumsal cinsiyet rolleri açısından bakıldığında Bozköy erkeği kadın kadar üretken, becerikli ve yüksek organizasyon becerisine sahip değildir. Ancak kamusal alanlardaki etkinliği baskındır. Ekonomik sistemleri, örf ve adetleri asırlardır erkek yönlendirmektedir. Mevcut çalışmada cinsiyete dayalı iş bölümünü mekân içi ve mekân dışı mimari öğeler göz önüne alınarak değerlendirilmiştir. Hayvancılık öncesi ve zeytincilik ile birlikte oluşan yeni ekonomik sistemin mimariye yansımaları üzerinde durularak mimari değişikliklerin toplumsal cinsiyet rolleri üzerindeki etkilerine detaylı değinilmiştir.

Bozköy'de gerçekleştirilen yüzey araştırmalarına, sosyo-ekonomik, kültürel, etnografik ve mimari çalışmalara ilaveten bu çalışmada toplumsal cinsiyet arkeolojisi ve toplumsal cinsiyet bazlı etnografik bakış açıları ile geçmişin Bozköy-Hanaytepe Höyüğ̈̈'nü gelecek yıllarda çalışacak ekiplere, toplumsal cinsiyet rollerini arkeolojik veriler 1şığında değerlendirmeleri önerisi sunulmaktadır. Arkeolojik buluntular belgelenirken nesnenin ardındaki kadın veya erkek rolü göz ardı edilmektedir. Kazıp çıkarılan mekânlar birilerinin inşa ettiği, yaşadığı, izler bıraktığı mimari birimlerdir; o mekânların içinde yaşamış olanları bilimsellik çerçevesinde "cinsiyetsiz" varsaymış ${ }^{91}$, gözümüzden sürekli kaçırarak hatta yeri geldiğinde sadece erkek egemen bakış açısı sergilemişizdir. Mekânlardaki buluntulara bakarak o mekânların ne işe yaramış olduğunu düşünerek işlik, avlu, ev, mutfak şeklinde adlandırıp bireyleri o mekânlara yerleştirmekten uzak durmuş, mekânları boş bırakmışızdır ${ }^{92}$. Toplumsal cinsiyet rollerini veya iş bölümlerini çalışmadaki amaç bugünün ve geçmişin hakim olan "ana tanrıça", "anaerkil" veya "ataerkil" anlayışların ötesinde toplumların değişen coğrafyalarda, değişen sosyo-ekonomik sistemler içinde farklı özellikleri olduğunu tekrar hatırlamaktır. Toplumlar her yerde ve zamanda aynı özellikleri sergilemez; bilakis farklı özellikleri var olmakla beraber genellemeler yoluyla her yerleşmeye aynı yargılarla varılamaz.

Kalkolitik veya İlk Tunç Çăgı (İTÇ) Bozköy Hanaytepe Höyüğü’ndeki topluma, günümüz köy yaşamı özelliklerini analoji yaparak arkeolojik çalışmalara başlamak fayda sağlayabilir. Ancak bahsedildiği gibi toplumlar zamana, koşullara ve yere göre değişiklikler gösterebilir. 1960 yılına kadar ekonomisi hayvancılığa bağlı Bozköy halkının gelen muhacirlerin etkisi ile zeytinciliğe yönelmeleri Kalkolitik veya İTÇ Bozköy toplumu için de uyarlanabilir. Bozköy'de değişen ekonomik sistemle değişen sosyal yapıyı, o sosyal yapının değiştirdiği mimariyi, değişen besin ekonomisi, farklı ticaret yolları, çok

\footnotetext{
${ }^{90}$ Ertuğ, 2010: 93.

91 Tringham, 1991: 94.

${ }^{92}$ Ertuğ, 2010: 80.
} 
kültürlülüğü düşünerek geçmişe günümüzden benzer açılarla bakmak mümkündür. Türkiye'de akademik alanda cinsiyet dinamiklerini temel alarak mekân analizine girişen ya da cinsiyet analizlerine mekânsal süreçleri ayrılmaz bir bileşen olarak dahil eden çalışmalara ihtiyaç vardır ${ }^{93}$. Cinsiyete dayalı iş bölümü veya toplumsal cinsiyet rollerini anlamaya yönelik etnoarkeolojik çalışmaların yapılması farklı disiplinlerin bir arada görünür kılınmasını sağlayacaktır.

\section{TEŞEKKÜR}

Bozköy’deki çalışmaya bizleri davet eden, ilgilenen, katkıları bulunan Mimar İsmail Erten ve değerli ailesine; ayrıca yüksek lisans dönemimde etnoarkeoloji dersini veren ve çalışmanın gerçekleşmesi için önerilerde bulunan Çanakkale Onsekiz Mart Üniversitesi öğretim üyesi Prof. Dr. Rüstem Aslan’a teşekkür ederim. Çalışma esnasında yanımda olan ve fikirleri ile yön veren Dr. Öğr. Üyesi Meral Başaran Mutlu'ya en içten duygularımla teşekkür ederim. Farklı dönemlerde muhtarlık görevini yapan Yahya Üner'e ve Cavit Tuğral'a zaman ayırıp verdikleri değerli bilgiler için teşekkür ediyorum.

${ }^{93}$ Çakır, 2010: 135 . 


\section{KAYNAKÇA}

Akgün, S. E. (2010). Troas Bölgesi İlk Tunç Çağı Konut Tipolojisinin Arkeolojik ve Etnoarkeolojik Açıdan Değerlendirilmesi. Çanakkale Onsekiz Mart Üniversitesi Sosyal Bilimler Enstitüsü, Yayınlanmamış Yüksek Lisans Tezi, Çanakkale.

Alkım, H. (1983). Ein Versuch der Interpretation der Holzarchitektur von İkiztepe. Beitrage zum Altertumskunde Kleinasiens. Fetschrift für Kurt Bittel, R.M. Boehmer, H. Hauptmann. (eds.) Mainz: Rudolp Habelt, 13-27.

Angle, M.; Dottarelli, R. (1990). Ethnoarchaeology at Uslu (Elazığ): a preliminary report on contemporary pottery manufacture in eastern Anatolia. VII. Araştırma Sonuçları Toplant1s1 II, 467-479.

Arsebük, G. (1983). Dünden Bugüne Arkeoloji. Cumhuriyet Dönemi Türkiye Ansiklopedisi, Cilt 1, İstanbul: İletişim Yayınları, 66-75.

Arslan, A. (2015). Gendered Lifeways in Central Anatolia in the Neolithic and The Early Chalcolithic Periods (8500-5000 BC). Koç Üniversitesi Sosyal Bilimler Enstitüsü, Yayınlanmamış Yüksek Lisans Tezi, İstanbul.

Aslan, R. (1997). Troia und Seine Siedlungskammer: Vom Neolithikum bis zu den Anfangen des Historischen Nationalparks, Magisterarbeit im Fach Ur- und Frühgeschichte und Archäologie des Mittelalters an der Eberhard -Karls Universität Tubingen, Fakultät für Kultur - Wissenschaften.

Aslan, R. (2011). Siedlung Und Gesellschaft In Der Troas: Eine Ethnoarchaologische Studie Im Bereich Des Nationalparks Troia Und Seiner Umgebung. Çanakkale: Studies On The Troad-1, Troia Vakfi Yayınları.

Aslan, R.; Blum, S. W. E (2004). Darı Köy: Ethnoarchaeological investigations into the emergence of archaeological variability". Turan Takaoğlu (ed.), Ethnoarchaeological Investigations in Rural Anatolia Vol. I. İstanbul: Ege Yayınları, 127-149.

Aslan, R.; Blum, S. W. E.; Kienlin, T. L.; Uysal, F. E.; Kirschner, S. (2011). 2009 Y1lı Bozköy-Hanaytepe ve Çevresi Prehistorik Dönem Yüzey Araştırması. Araştırma Sonuçları Toplantısı 28 (2), 291-302.

Aurenche, O.; Calley, S. (1984). Une expérience ethnoarchéologique: Cafer Höyük (Turquie). Paléorient 10, 122-127.

Aurenche, O.; Bazin, M.; Dadler, S. (1997). Villages engloutis: enquête ethnoarcheologique à Cafer Höyük (Vallée de l'Euphrate). Paris: De Boccard.

Binford, L. R. (1962). Archaeology as Anthropology. American Antiquity 28/2, 217-255.

Blum, S. W. E. (2000). Işıklar: Ethnoarchäologische Untersuchungen zur Formation und Transformation archäologischer Siedlungskontexte. Magister Artium im Fach Urund Frühgeschichte an der Eberhard Karls Universität Tübingen. 
Blum, S. W. E. (2003). Işıklar: Ethnoarchäologische Untersuchungen zur Formation und Transformation archäologischer Siedlungskontexte, Studies in Ethnoarchaeology, Vol. 1, Remshalden: Verlag Bernhard Albert Greiner.

Bordaz, J. (1965). The threshing sledge. Natural History 74, 26-29.

Bordaz, J. (1969). Flint flaking in Turkey. Natural History 78, 73-79.

Conkey, M.W.; Spector, J. (1984). Archaeology and the Study of Gender. Advances in Archaeological Method and Theory 7, 1-38.

Crane, H. (1988). Traditional pottery making in the Sardis region of western Anatolia. Muqarnas 5, 9-20.

Çakır, S. (2010). Mekânın Kadınlar Açısından Kurgulanışına Kuramsal ve Tarihsel Süreç İçinde Bakmak. Kadın ve Mekân, Ayşen Akpınar, Gönül Bakay, Handan Dedehayır (der.), İstanbul: Turkuvaz Kitapçılık ve Yayıncılık, 133-149.

Çambel, H.; Braidwood, R. J.; Benedict, P.; Erinç, S.; Gordus, A. A.; Güney, D.; Jelinek, A. J.; Lawrance, B.; Özdoğan, M.; Whallon, R. J.; Wright, G. A. (1980). İstanbul ve Chicago Üniversiteleri Karma Projesi Güneydoğu Anadolu Tarihöncesi Araştırmaları. İstanbul: Edebiyat Fakültesi Basımevi.

Çavuşoğlu, İ. (2015). Kültürel Coğrafya Açısından Bir İnceleme: Çanakkale İlinde Geleneksel Köy Hayırları. Çanakkael Onsekiz Mart Üniversitesi Sosyal Bilimler Enstitüsü, Yayınlanmamış Yüksek Lisans Tezi, Çanakkale.

Çevik, A. (2009). Social meaning of household spaces, A modern meterial culture study in an Anatolian village. Archaeological Dialogues 2(1), 39-50.

David, N.; Kramer, C. (2001). Ethnoarchaeology in Action. Cambrdige University Press.

Dittemore, M. R. (1983). Zemzemiye: An Ethnoarchaeological Study of a Turkish Village. University of Chicago, Ph.D. Dissertation.

Edgü, E. (2010). Evin Direği, Sokağın Bekçisi. Kadın ve Mekân, Ayşen Akpınar, Gönül Bakay, Handan Dedehayır (der.), İstanbul: Turkuvaz Kitapçılık ve Yayıncılık, 7279.

Ertuğ, F. (1998). Orta Anadolu'da bir etnoarkeoloji ve etnobotani çalışması. Karatepe'deki Işık: Halet Çambel'e Sunulan Yazılar, G. Arsebük, M.J. Mellink, W. Schirmer (eds.), İstanbul: Ege Yayınları, 325-338.

Ertuğ, F. (2002). Pounders and Grinders in a modern central Anatolian village. Moudre et broyer. H. Procopiou, R. Treuil (eds), Paris : CTHS, 211-225. 
Ertuğ, F. (2010). Geçmişten Bugüne Anadolu Kırsalında Kadın - Mekan İlişkileri. Kadın ve Mekân, Ayşen Akpınar, Gönül Bakay, Handan Dedehayır (der.), İstanbul: Turkuvaz Kitapçılık ve Yayıncılık, 80-93.

Filgis, M. N.: Blum, S. W. E.; Aslan, R. (2005). Traditionelle Kalkbrennerei in Gökcebayir, Nordwesttürkei. Studia Troica 15, Manfred Korfmann (ed.), Mainz: Philipp von Zabern, 222-245.

Gezer, H. (2010). Mekânların Kadınsı Anlatımları. Kadın ve Mekân, Ayşen Akpınar, Gönül Bakay, Handan Dedehayır (der.), İstanbul: Turkuvaz Kitapçılık ve Yayınc1lık, 94-109.

Gürel, C. (2016). Antik Troas Bölgesinde Zeytincilik Etnoarkeolojik Bir Yaklaşım. Çanakkale Onsekiz Mart Üniversitesi Sosyal Bilimler Enstitüsü, Yayınlanmamış Yüksek Lisans Tezi, Çanakkale.

Gürsan-Salzmann, A. (2011). The Women of Yassıhöyük, Turkey: Changing Roles in a New Economy. Expedition 4, 26-31.

Harlan, J. (1967). A wild wheat harvest in Turkey. Archaeology 20, 199-201.

Hendon, J. (2000). Round Structures, Household Identity, and Public Performance in Preclassic Maya. Latin American Antiquity, 11(3): 299-301.

Hodder, I. (1982). Symbols in action: Ethnoarchaeological studies of material culture. Cambridge: Cambridge University Press.

Hummon, D. M. (1984). House, Home\&Identity: Sociological Observations on Recent Research. An International and Interdisciplinary Conference on Built Form and Culture Research, KU Press, Lawrence, Exxon Education Foundation.

Kalkan, A. (2009). Etnoarkeolojinin Anadolu'da Uygulanabilirliği. Adnan Menderes Üniversitesi Sosyal Bilimler Enstitüsü, Yayınlanmamış Yüksek Lisans Tezi, Aydin.

Koşay, H. Z. (1939). Etnografya ve Folklor Kılavuzu. Ankara: Ulusal Matbaa.

Kosay, H. Z. (1970). Pulur-Sakyol Kazısı 1968 Ön Raporu. Keban Projesi 1968 Yaz Çalışmaları. Ankara: ODTÜ, 139-142.

Kosay, H. Z. (1971). Pulur-Sakyol Kazısı. Keban Projesi 1969 Çalışmaları. Ankara: ODTÜ, 99-101.

Kosay, H. Z. (1972). Pulur-Sakyol Kazısı 1970. Keban Projesi 1970 Çalışmaları. Ankara: ODTÜ, 127-132.

Koşay, Z. K. (1974). Etnografya Folklor Dil Tarih v.d. Konularda Makaleler ve İncelemeler. Ankara: Ayyıldız Matbaası. 
Levy, E. J. (1981). Religious Ritual and Social Stratification in Prehistoric Societies: An Example from Bronze Age Denmark. History of Religions, 21 (2), 172-188.

Moss, L. M. (2005). Rifts in the Theoretical Landscape of Archaeology in the United States: A Comment on Hegmon and Watkins. American Antiquity, 70 (3), 581587.

Mutlu, S. (2017). Neolitik ve Kalkolitik Dönem Batı Anadolu Antropomorfik Figürinlerinde Cinsiyet ve Sembolizm. Çanakkale Onsekiz Mart Üniversitesi Sosyal Bilimler Enstitüsü, Yayınlanmamış Yüksek Lisans Tezi, Çanakkale.

Naumann, R. (1998). Eski Anadolu Mimarlığı. Beral Madra (çev.), Ankara: Türk Tarih Kurumu Basımevi.

Nelson, S. M. (1997). Gender in Archaeology: Analyzing Power and Prestige. Walnut Creek, Calif.: AltaMira Press.

Özdemir, A. (2013). Kalkolitik Smitheion (Gülpınar) Yerleşiminde Hasırcılık ve Dokumacılık. Çanakkale: Studies On The Troad-2, Troia Vakfı Yayınları.

Özdemir, A; Bamyacı, O. (2019). Kuzeybatı Anadolu'da (Kıyı Troas Bölgesi) Kırsal Hayvancılık ve Arazi Kullanımı: Etnoarkeolojik Bir Bakış. Fırat Üniversitesi Sosyal Bilimler Dergisi 29 (1), 17-25.

Özdoğan, M. (2011). Arkeolojik Kazılar Bilimsel Çalışma mı? Toprak Hafriyatı mı?. İstanbul: Arkeoloji ve Sanat Yayınları.

Polat, F. (2013). Doğu Anadolu Yayla Kültürü ve Yayla Mimarisi: Etnoarkeolojik Bir Bakış. İstanbul: Arkeoloji ve Sanat Yayınları.

Polat, F. (2018a). Tevfikiye Köyü: Son Troialılar. Çanakkale: Çanakkale Kitaplığı.

Polat, F. (2018b). Yeniköy: Troia’nın İlk Savunma Hattı. Çanakkale: Çanakkale Kitaplığı.

Polat, F.; Aslan, R.; Erten, İ. (2012). Troas Bölgesi’nde Farklı Zamanlarda İki Yerleşim ve Etnoarkeoloji Bozköy Köyü - Bozköy Hanaytepe Höyüğü. Bozköy Hanaytepe ve Çevresi Prehistorik Dönem Araştırmaları. Rüstem Aslan, Fecri Polat (eds.), Çanakkale: Troia Vakfı Yayınları, 111-152.

Polat, F; Yeleş, H. (2017). Halileli: Troia Ovasında Bir Köy. Çanakkale Kitaplığı: Çanakkale.

Sezgin, E. (2019). Toplumsal Cinsiyet Rolleri Açısından Erken Tunç Çağında Ege Dünyası. Ege Üniversitesi Sosyal Bilimler Enstitüsü, Yayınlanmamış Yüksek Lisans Tezi, İzmir.

Steele, C.N. (1971). The potters of Sorkun Village in Northwest Anatolia. The study of a Present day Primitive Pottery Industry and its Relevance to Archaeology. Oxford University, Unpublished Ph.D. Dissertation. 
Takaoğlu, T. (ed.) (2004). Ethnoarchaeological Investigations in Rural Anatolia Volume I, İstanbul: Ege Yayınları.

Takaoğlu, T. (ed.) (2005a). Ethnoarchaeological Investigations in Rural Anatolia Volume II, İstanbul: Ege Yayınları.

Takaoğlu, T. (2005b). Kuzeybatı Anadolu'da Gülpınar'dan Prehistorik Bir Yas Tutan Heykelcik. Arkeoloji Anadolu \& Avrasya Dergisi, 6-7.

Takaoğlu, T. (2007a). Turan Takaoğlu'na Ait 2007-2008 Güz Yarıyılı ARK 517 Etnoarkeoloji Yüksek Lisans Ders Notlanı (18 Sayfa, Teksir), Çanakkale Onsekiz Mart Üniversitesi Sosyal Bilimler Enstitüsü Arkeoloji Ana Bilim Dalı, Çanakkale.

Takaoğlu, T. (ed.) (2007b). Ethnoarchaeological Investigations in Rural Anatolia Volume III, İstanbul: Ege Yayınları.

Takaoğlu, T. (ed.) (2008). Ethnoarchaeological Investigations in Rural Anatolia Volume IV, İstanbul: Ege Yayınları.

Takaoğlu, T.; Özdemir, A. (2013a). Coşkuntepe A Neolithic Village in the Coastal Troad. The Neolithic in Turkey Northwestern Turkey and Istanbul, Mehmet Özdoğan, Nezih Başgelen, Peter Kuniholm (eds.), İstanbul: Arkeoloji ve Sanat Yayınları, 3543.

Takaoğlu, T.; Özdemir, A. (2013b). Smitheion Öncesi: Prehistorik Yerleşim. Smintheion Apollon Smintheus'un İzinde, Coşkun Özgünel (ed.), İstanbul: Ege Yayınları, 1528.

Tanner, N.; Adrienne Z. (1976). Women in Evolution. Part I: Innovation and Selection in Human Origins. Signs, Vol. 1 (3), The Universitiy of Chicago Press, 585-608.

Tekkök, B. B. (2000). Pottery Production in the Troad: Ancient and Modern Akköy. Near Eastern Archaeology 63 (2), 94-101.

Tringham, R. E. (1991). Households with Faces: The Challenge of Gender in Prehistoric Architectural Remains. Engendering Archaeology, Women and Prehistory, J. M. Gero, M. W. Conkey (eds.), Oxford, Cambridge: B. Blackwell, 93-131.

Whallon, R. J.; Kantman, S. (1970). Keban Barajı Su Birikim Alanı Yüzey Araştırması, 1967. Keban Projesi 1968 Yaz Çalışmaları. Ankara: ODTU, 1-6.

Wylie, A. (1997). The Engendering of Archaeology Refiguring Feminist Science Studies. Osiris, Women, Gender, and Science, Vol. 12, The University of Chicago Press, 80-99.

Yakar, J. (2007). Anadolu'nun Etnoarkeolojisi Tunç ve Demir Çağlarında Kırsal Kesimin Sosyo-Ekonomik Yapısı. Selen Hırçın Riegel (çev.), İstanbul, Homer Kitabevi. 
Yakar, J.; Garzon, J. L. (1976). The survival of ancient traditions in the popular architecture of north-central Turkey. Expedition 19: 43-47.

Yavşan, Ç. (2013). Kalkolitik Smintheion (Gülpınar) Kazıları Buluntusu Deniz Kabukları. Çanakkale: Troia Vakfı Yayınları.

Yelözer, S. (2016). Aşıklı Höyük Boncukları: Tipoloji, Tanım ve Sosyal Açıdan Değerlendirme. İstanbul Üniversitesi Sosyal Bilimler Enstitüsü, Yayınlanmamış Yüksek Lisans Tezi, İstanbul.

Yılmaz, D. (2013). Doğu Ege'de Yeni Bir Erken Tunç Çağı Kenti: Troas Bölgesi'nde Bozköy-Hanaytepe Yüzey Araştırmaları. The Journal of Academic Social Science Studies, 6 (5), 857-888.

https://sozluk.gov.tr/?kelime=ay\%C4\%B1t; erişim tarihi: 26.08.2020. 
Harita 1: Bozköy-Hanaytepe Höyüğü ve Çevresi (Yılmaz, 2013: Fig.2).

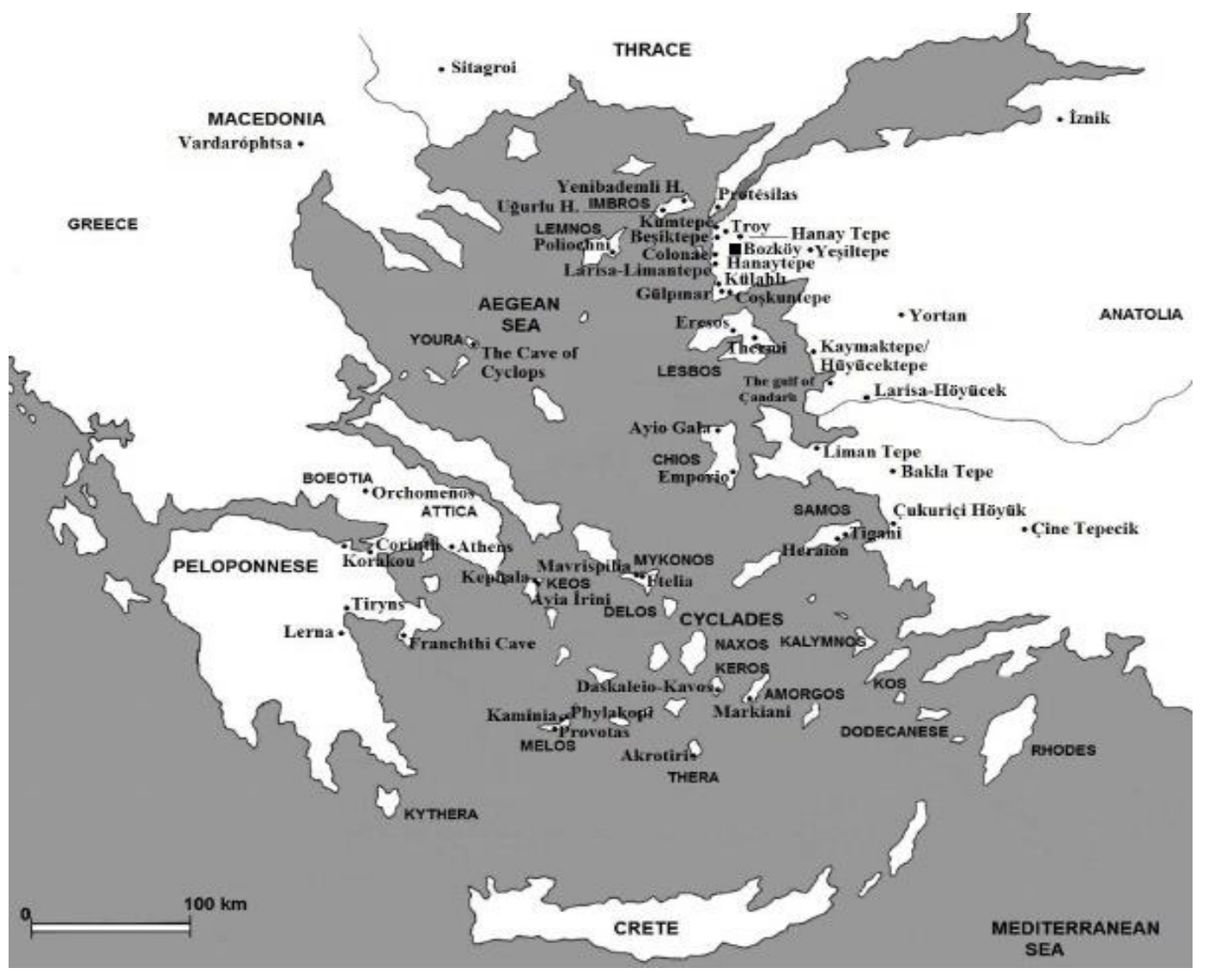

Resim 1: Zeytin ağaçları arasındaki Bozköy-Hanaytepe Höyüğü (Yılmaz, 2013: Fig. 1).

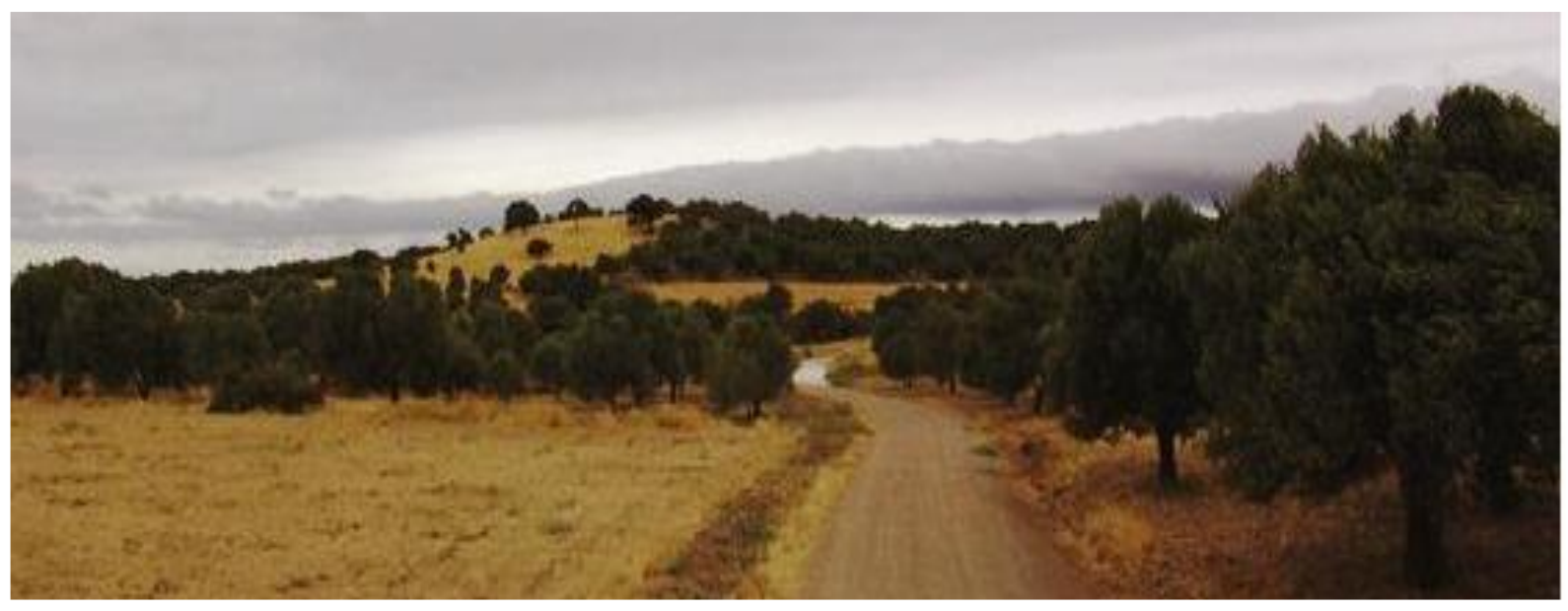


Resim 2: 1974 yılında kurulan zeytinyağı fabrikası terk edilmiştir.

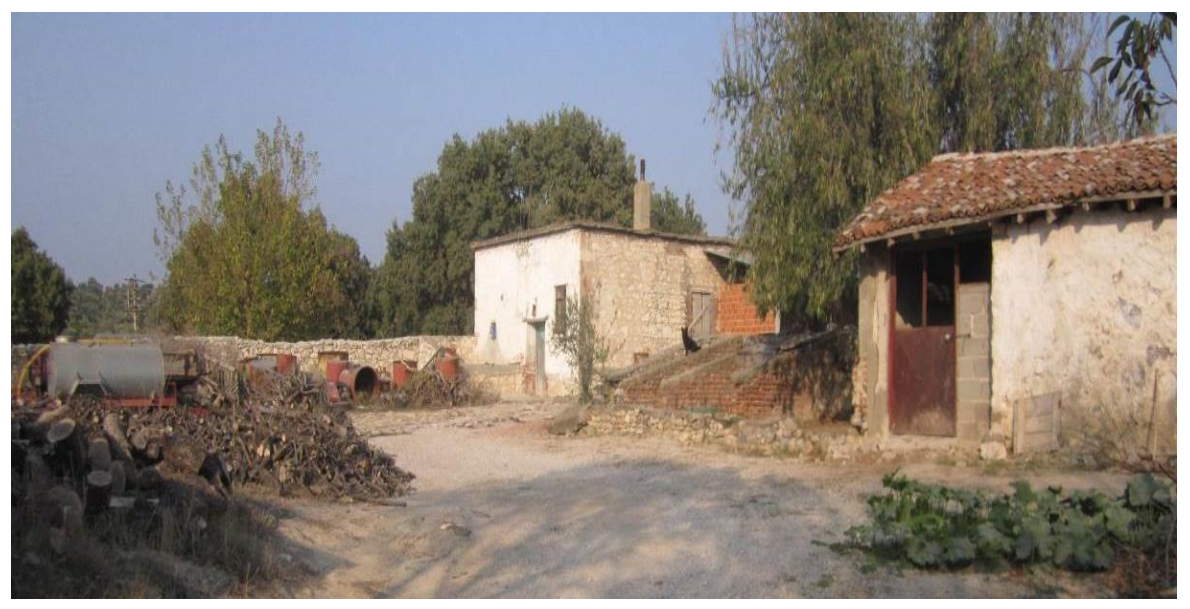

Resim 3: Zeytinyağı fabrikasının yerinde günümüzde geniş bahçeli ev bulunmaktadır (Fotoğraf, Cavit Tuğral).

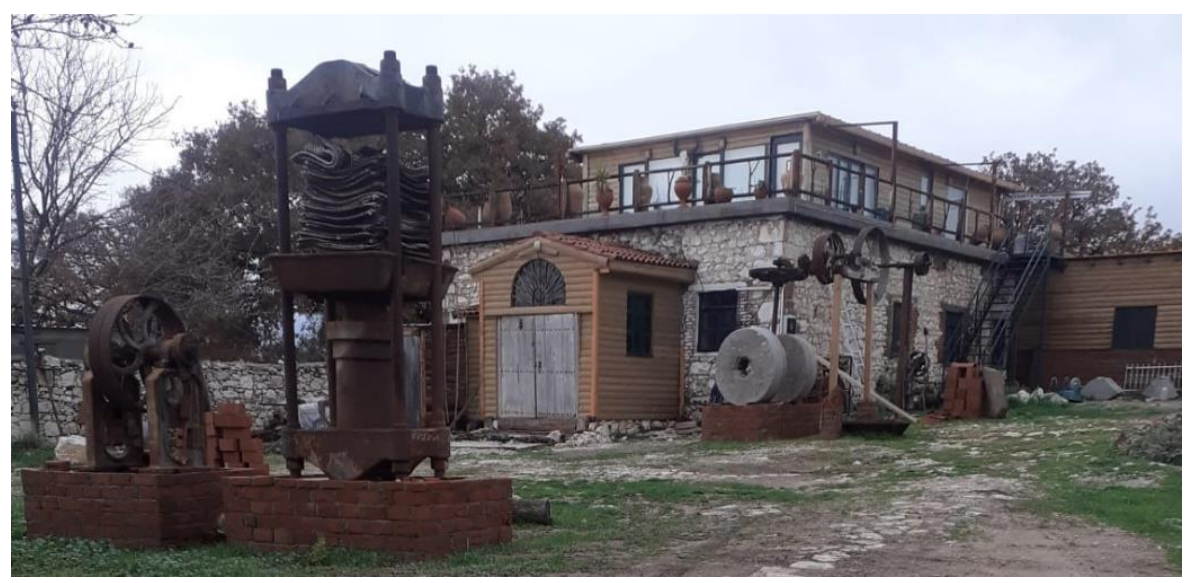

Resim 4: Geçmişin ekonomik değeri meşe palamudu depoları kültür sanat mekânı halini almıştır.

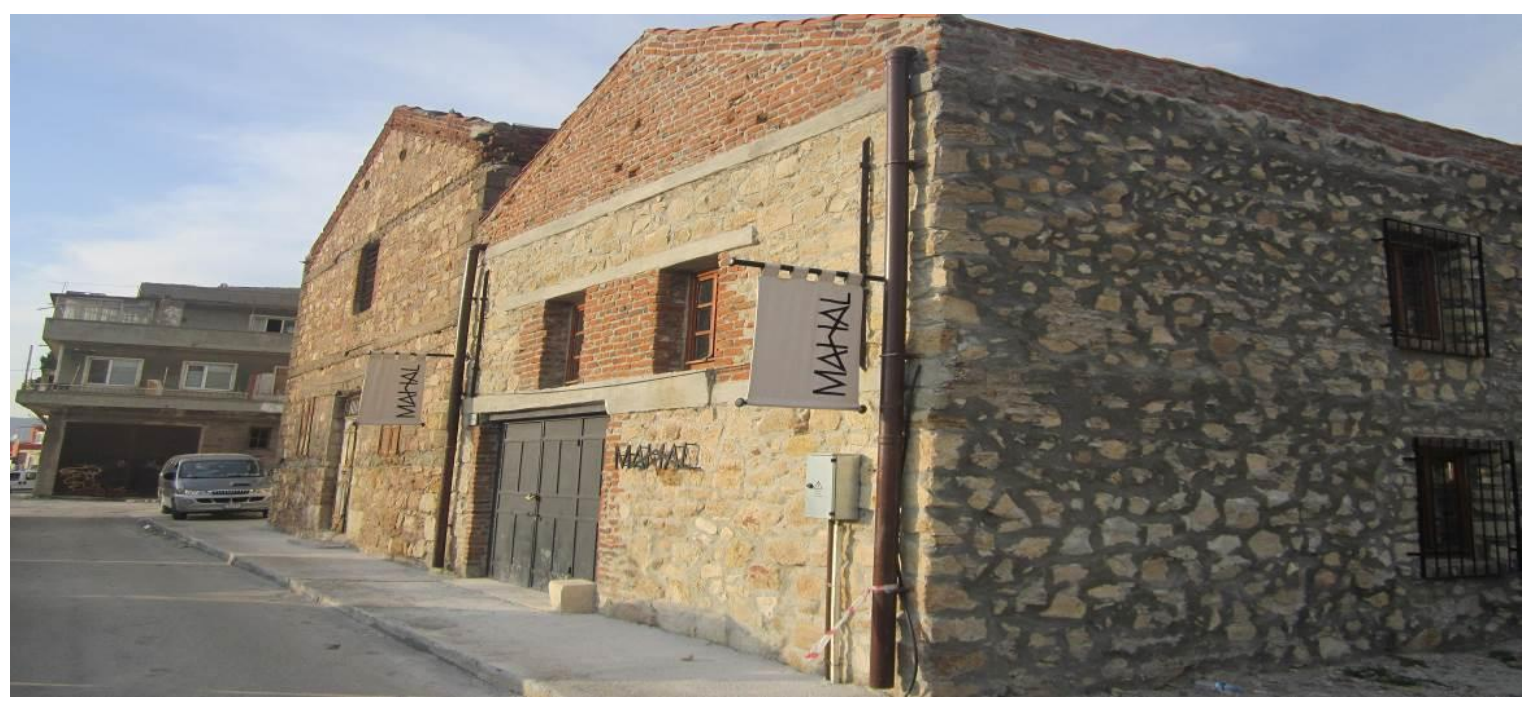


Resim 5: Bahçe işlerini yapan kadın.

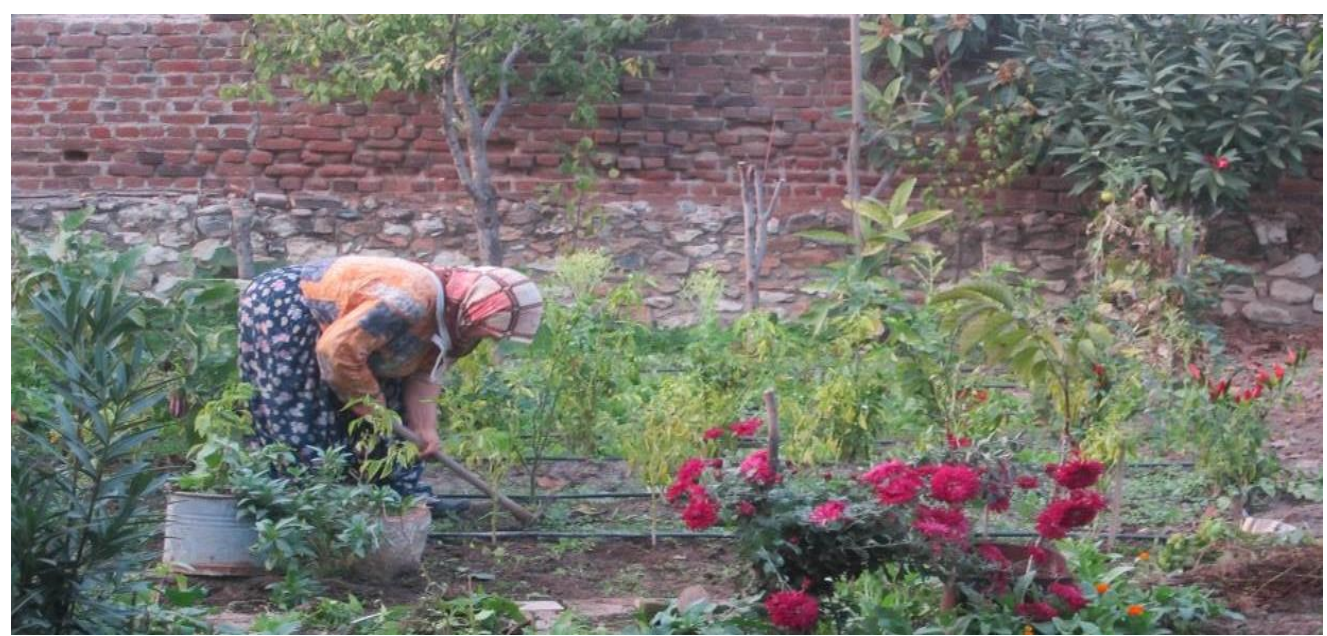

Resim 6: Dı̊s avluyu sokaktan ayıran yüksek duvarlar.

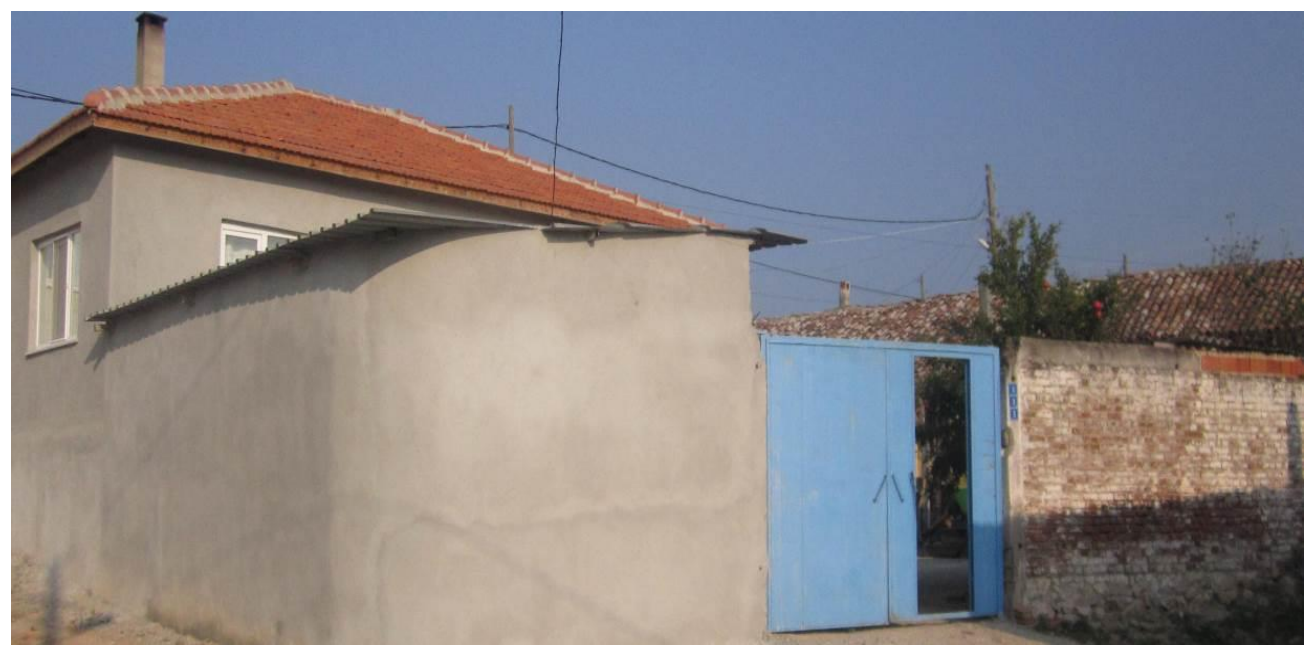

Resim 7: Yiyecek-içecek ambarı. $\quad$ Resim 8: Eski ahır ve samanlık. Bugün zeytincilikte farklı işlevlere sahiptir.

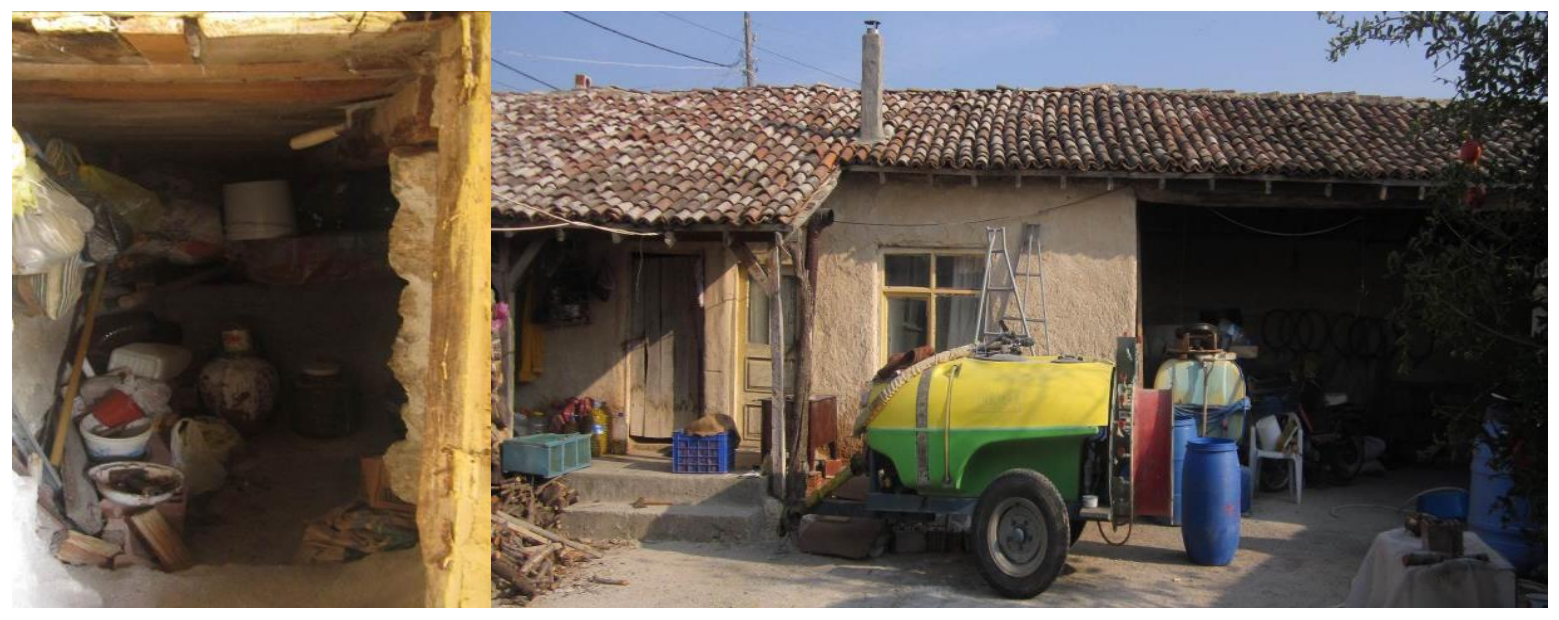


Resim 9: Hayvancılık döneminde kerpiç tuğla kullanılarak yapılmış bir ev.

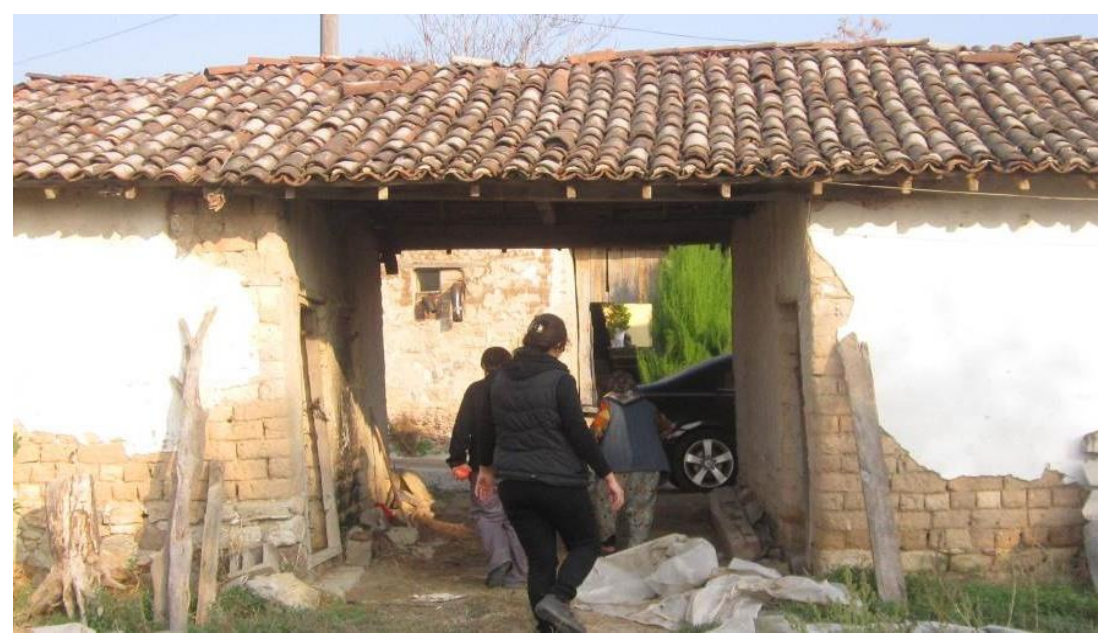

Resim 10: Zeytinyağı deposu. Resim 11: Avluda hasat döneminde büyük depolama kaplarında bekletilen zeytin.

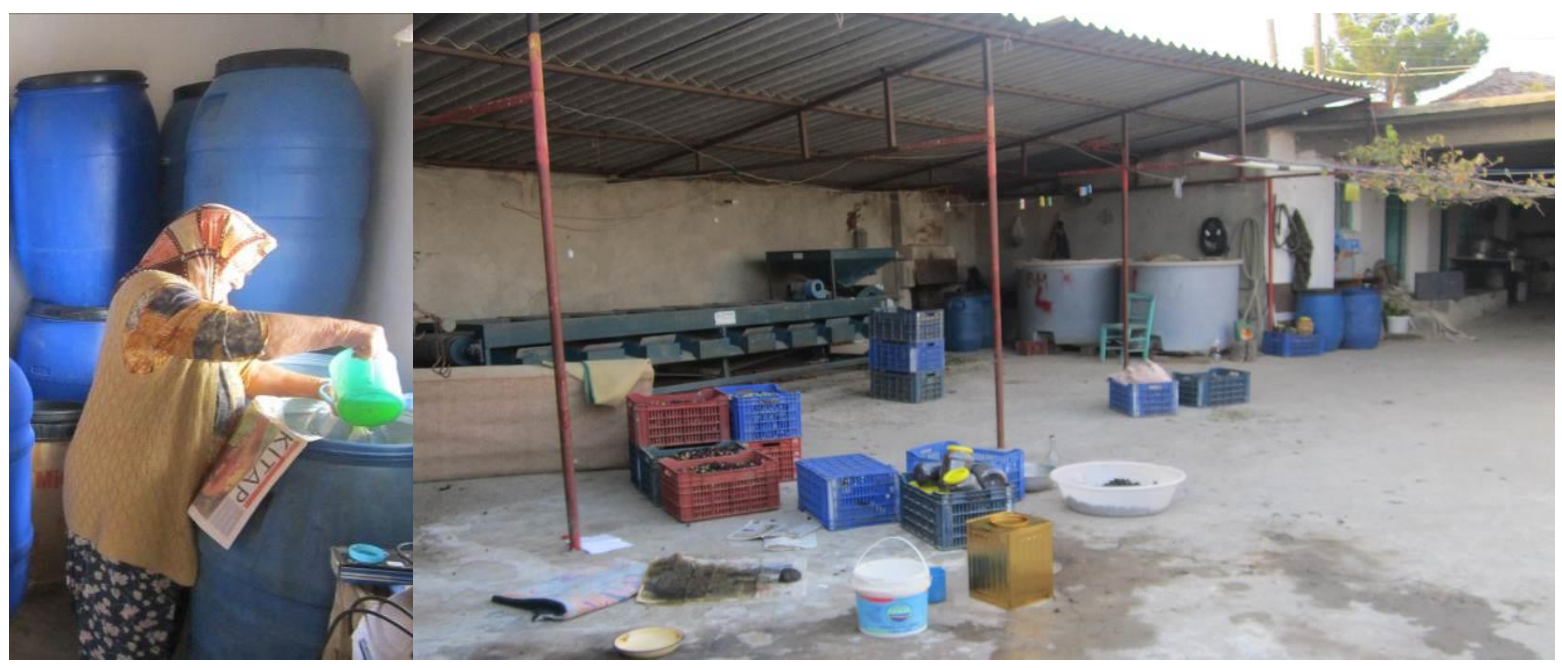

Resim 12: Kadınlar avludaki masada zeytini ayırmaktadır. Resim 13: Erkekler makinede zeytini ayırmaktadır.

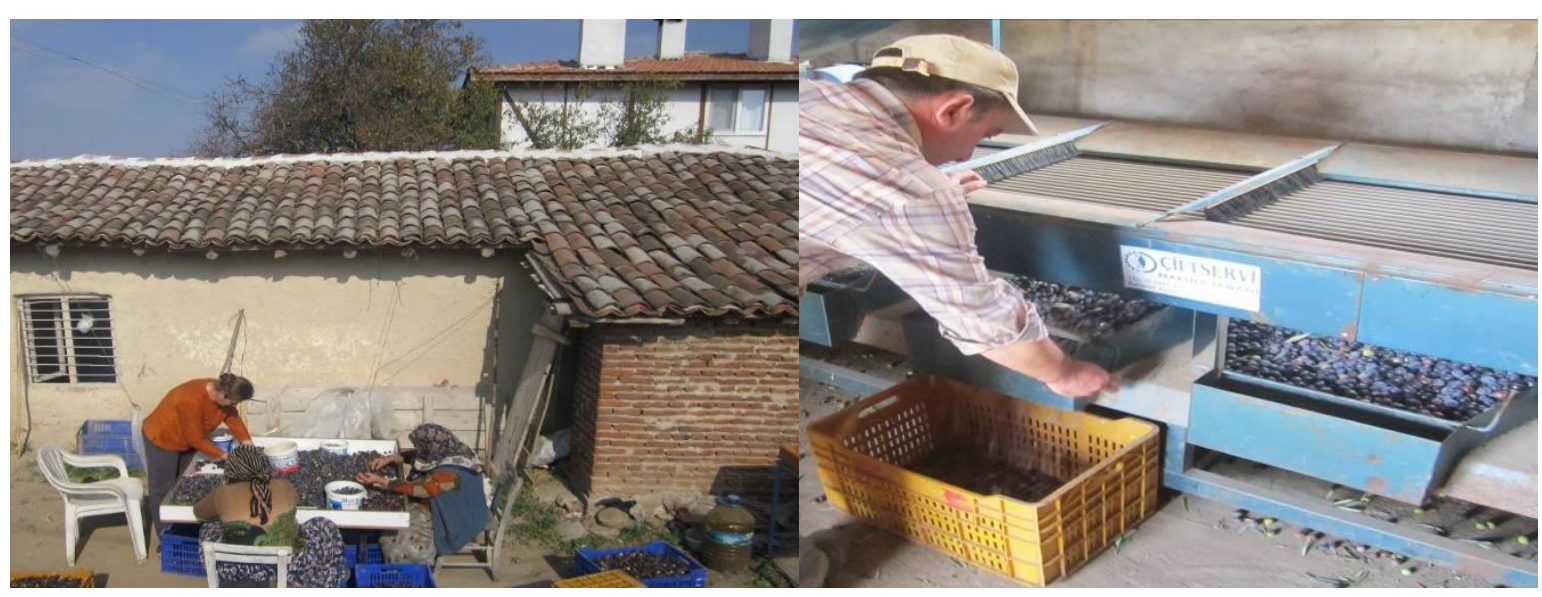




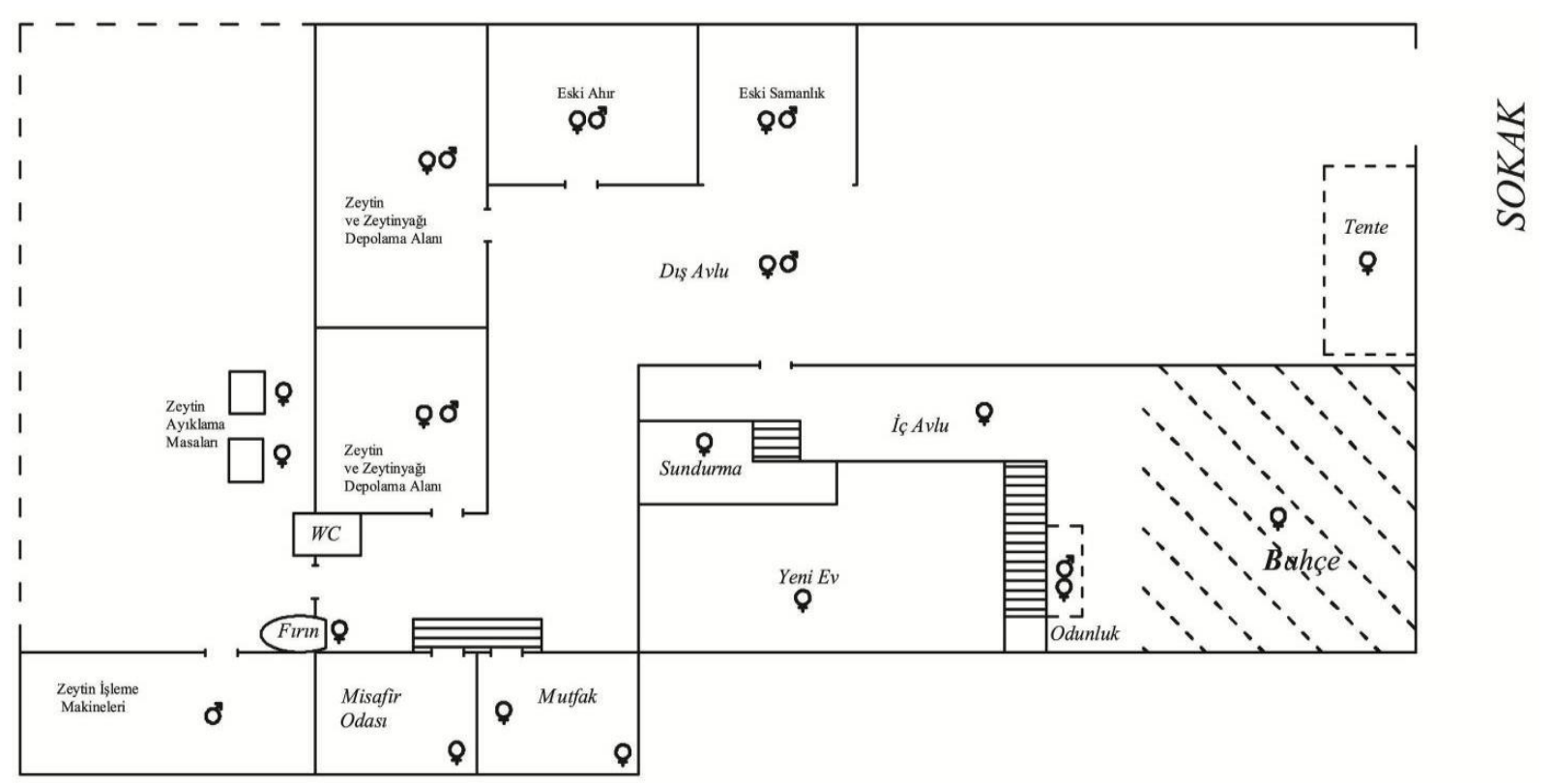

Plan 1: İsmail Erten'in baba evinde kadın ve erkeğin mekân kullanımı. Çizim: Meral BAŞARAN MUTLU.

Resim 14: Kadınların kurduğu ocaklar ve sobalar. $\quad$ Resim 15: Kadınların yemekte kullandığı tören kapları.

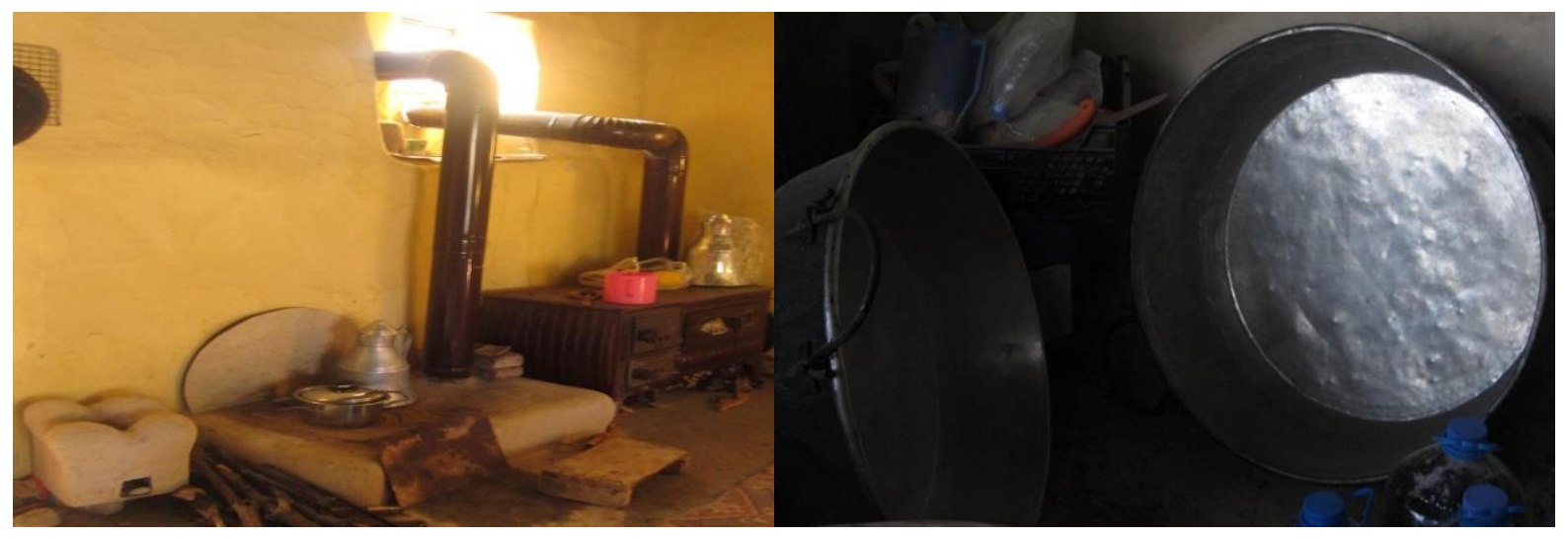

Resim 16: İçinde ekmek, börek, et pişen piniyet kabı. $\quad$ Resim 17: Avlulularda büyük fırınları kullanan kadınlar.

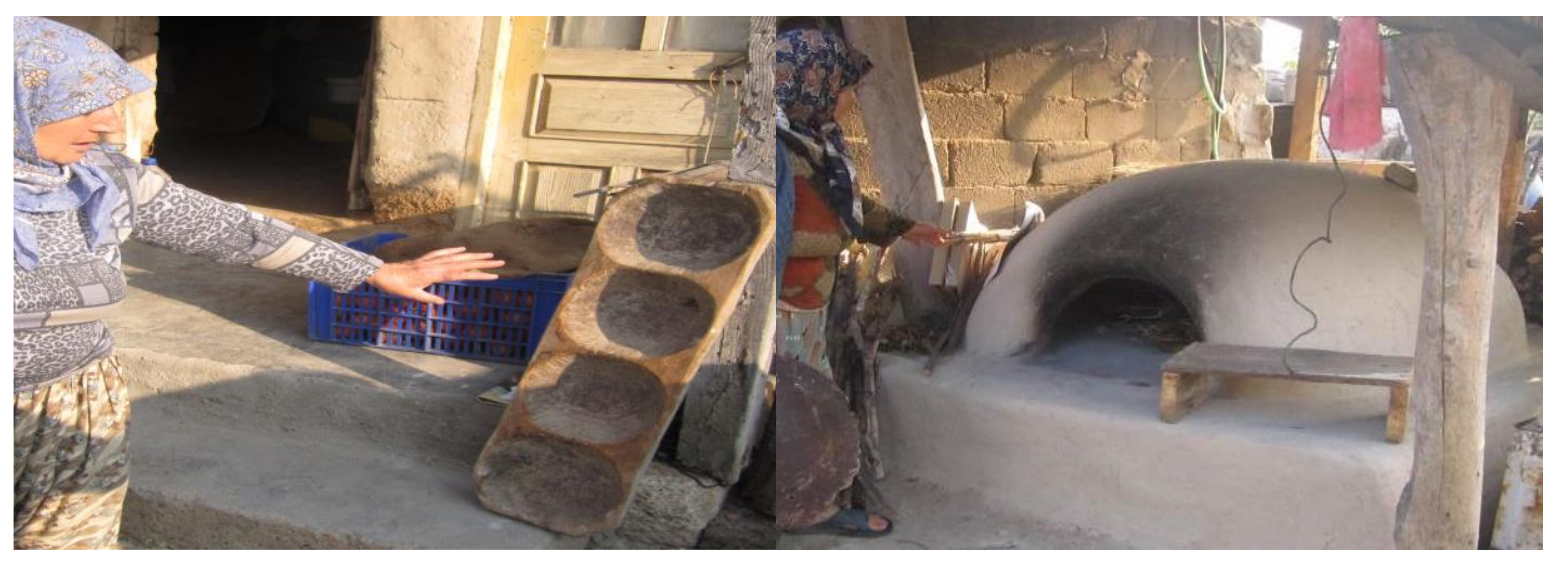


Resim 18: Veranda tipinde basamakla çıkılan sundurma. $\quad$ Resim 19: Yürüme zemininde dar sundurma örneği.

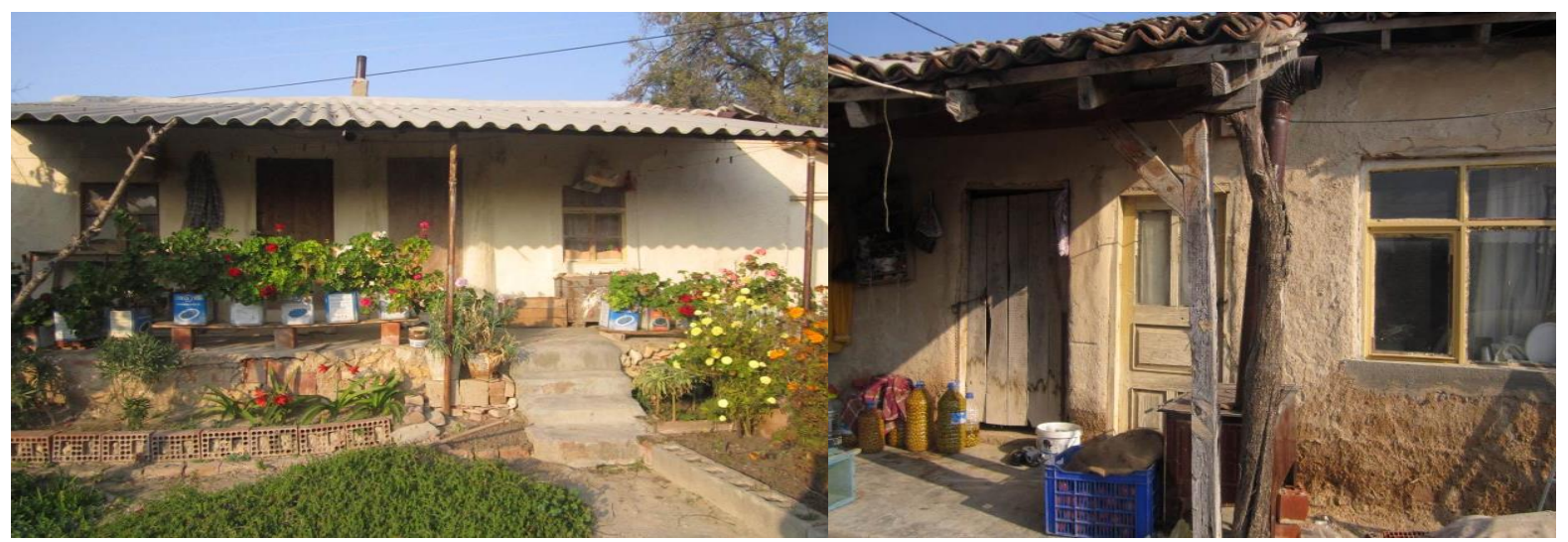

Resim 20: Su taşınan testiler.

Resim 21: Köy meydanındaki çeşme.

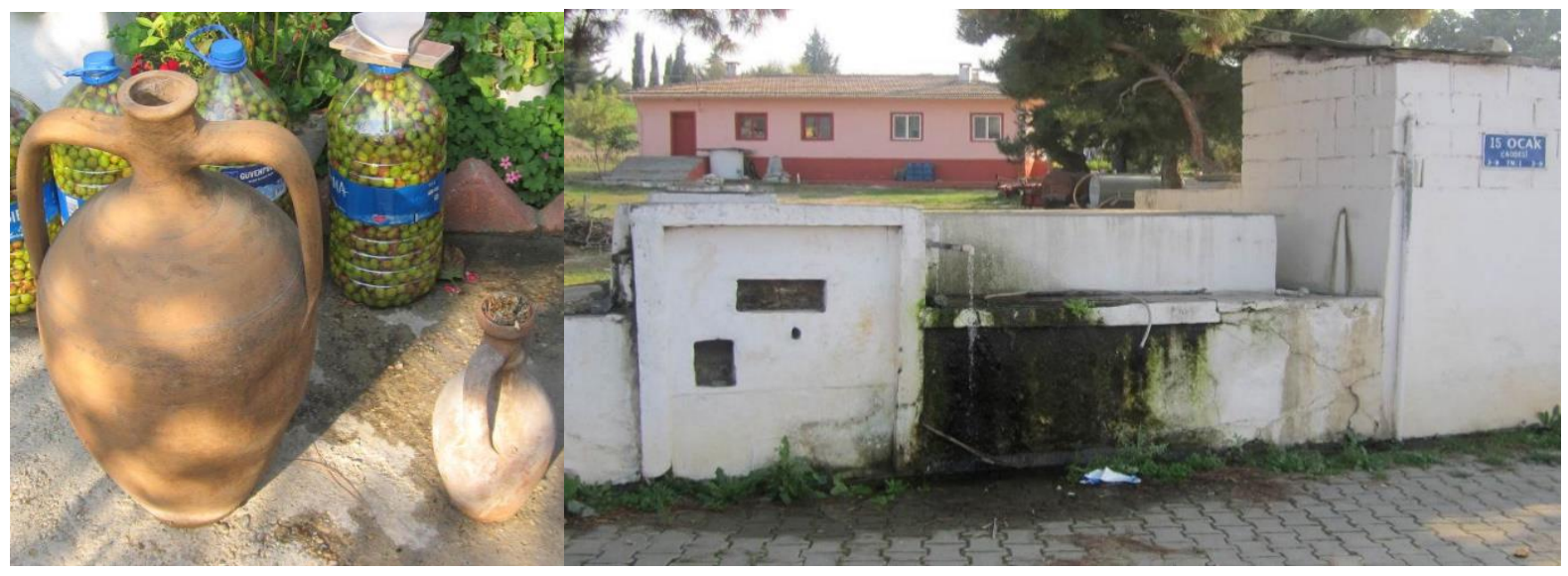

Resim 22: Bozköy meydanı çocukların oyun alanı.

Resim 23: Meydandaki muhtarlık ve kahve (Fotoğraf, Cavit Tuğral).

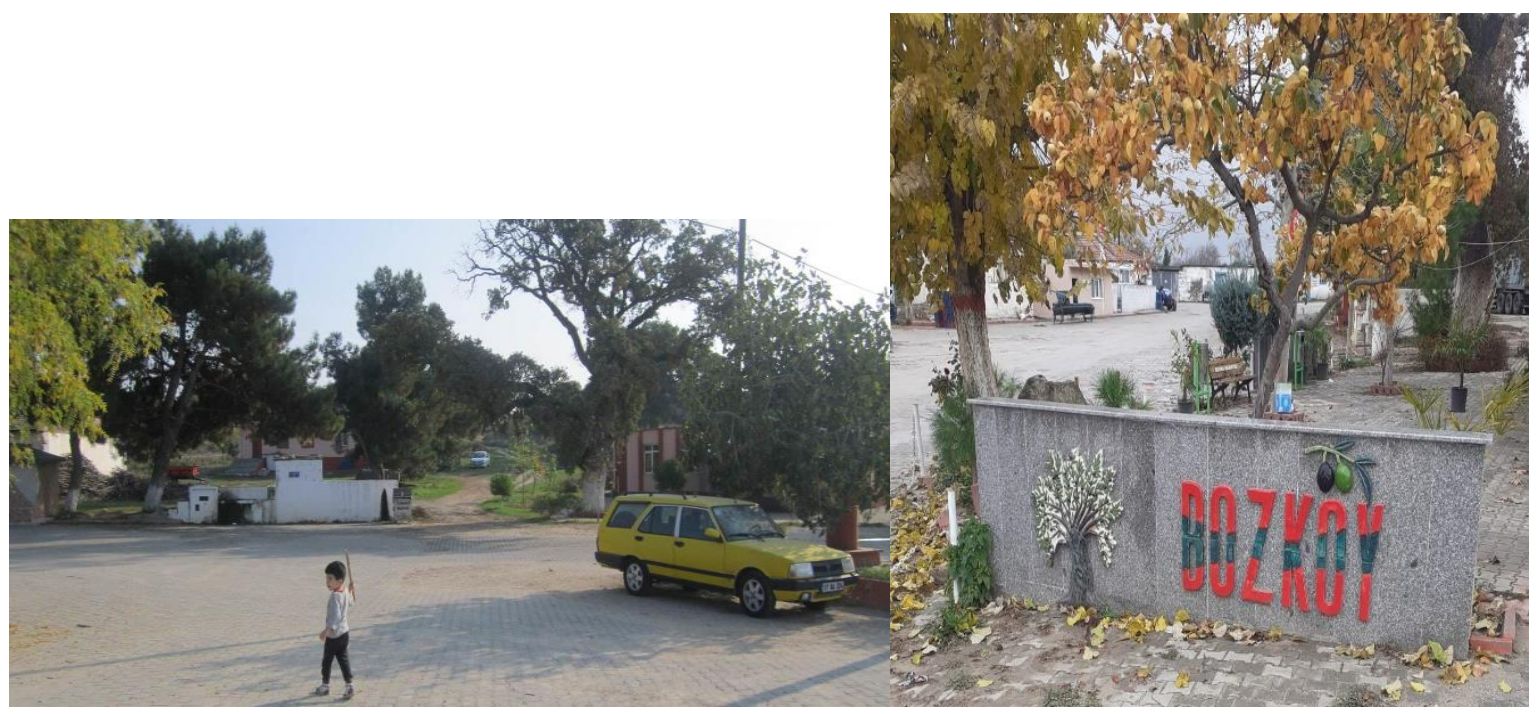


Resim 24: Bez çuval.

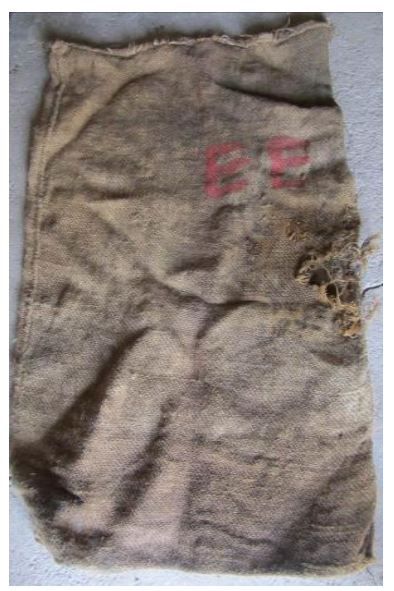

Resim 25: Kelatir, hasır küfe.

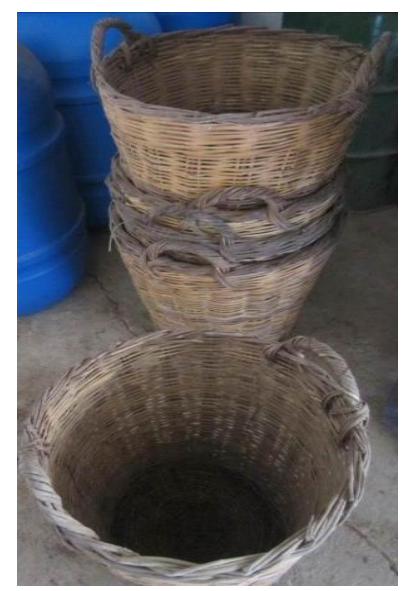

Resim 26: Bugün zeytinde plastik kasa kullanılır.

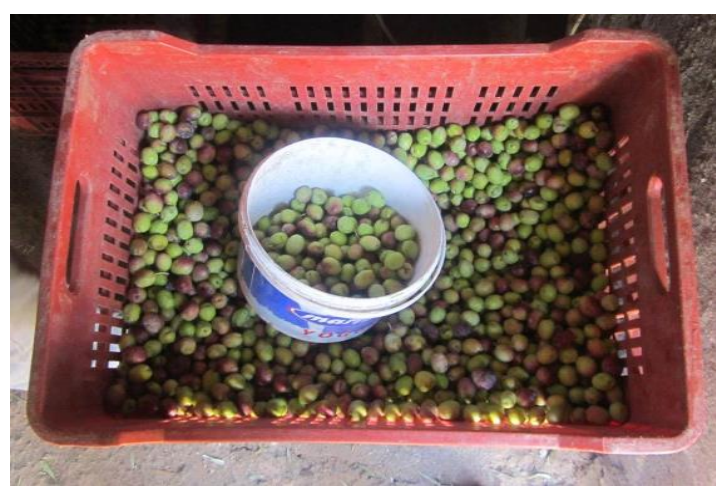

Resim 27: Kadınların kullandıkları tarak.

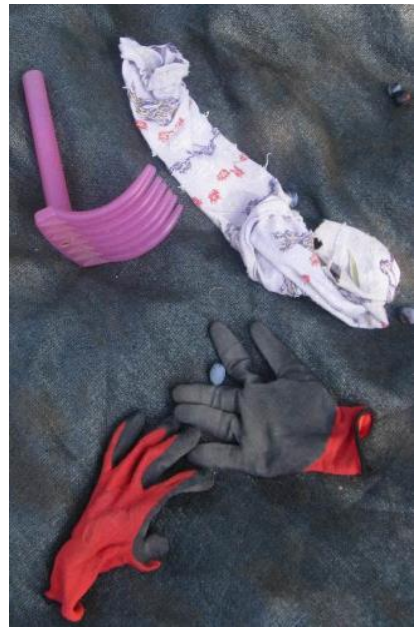

Resim 28: Kadınların zeytinde kullandıkları sepet.

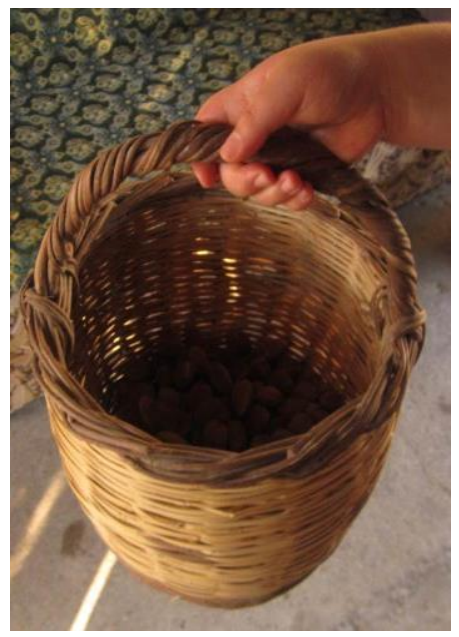

Resim 29: Erkekler kasaları traktöre taşımaktadır.

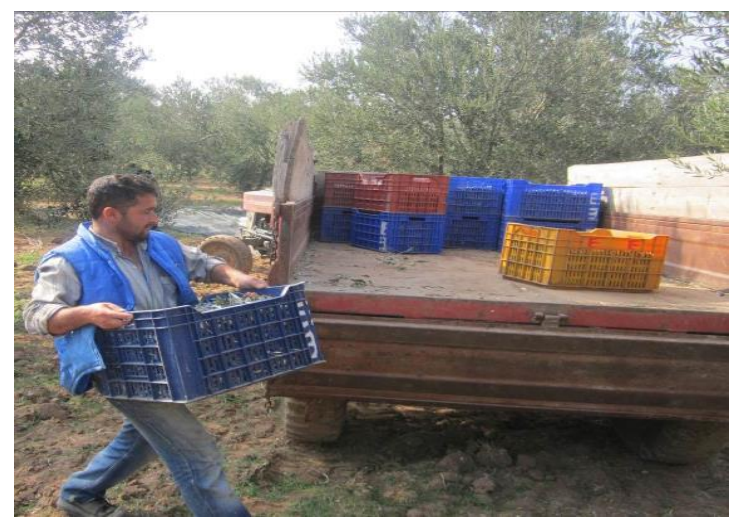

Resim 30: Kadınlar sehpa üzerinde zeytin toplamaktadır.

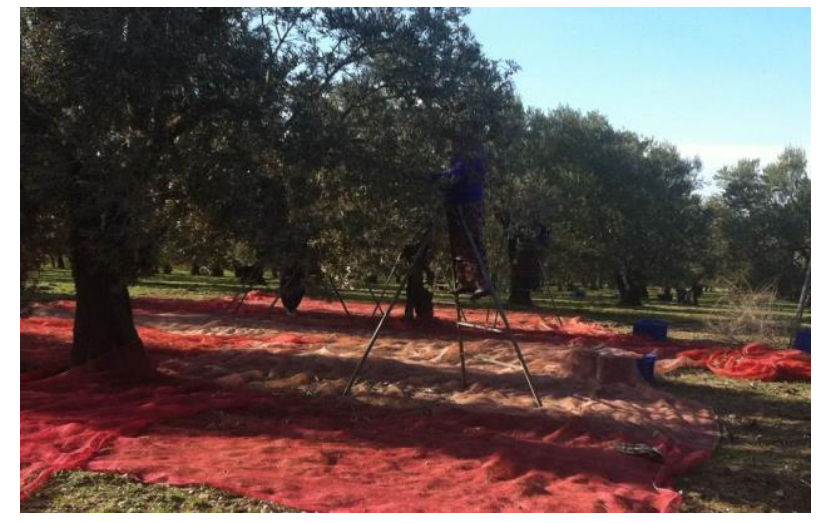

